\title{
Magnetic properties, anticancer and antibacterial effectiveness of sonochemically produced Ce3+/Dy3+ co-activated Mn-Zn nanospinel ferrites
}

munirah almessiere ( $\sim$ malmessiere@iau.edu.sa )

Imam Abdulrahman Bin Faisal University https://orcid.org/0000-0003-1651-3591

Yassine Slimani

Imam Abdulrahman Bin Faisal University

Suriya Rehman

Imam Abdulrahman Bin Faisal University

Firdos A. Khan

Imam Abdulrahman Bin Faisal University

S. Guner

RWTH aachen university

Sagar E. Shirsath

University of New South Wales

Abdulhadi Baykal

Imam Abdulrahman Bin Faisal University

\section{Research Article}

Keywords: nanospinel ferrites, sonochemical, anti-cancerous, bactericidal, magnetic properties, morphology, cytotoxicity, inhibitory activity

Posted Date: June 4th, 2020

DOI: https://doi.org/10.21203/rs.3.rs-32639/v1

License: (a) (1) This work is licensed under a Creative Commons Attribution 4.0 International License. Read Full License

Version of Record: A version of this preprint was published at Arabian Journal of Chemistry on October 1st, 2020. See the published version at https://doi.org/10.1016/j.arabjc.2020.08.017. 


\title{
Magnetic properties, anticancer and antibacterial effectiveness of sonochemically produced $\mathrm{Ce}^{3+} / \mathrm{Dy}^{3+}$ co-activated $\mathrm{Mn}-\mathrm{Zn}$ nanospinel ferrites
}

\author{
Munirah A. Almessiere ${ }^{a}$, Yassine Slimania, Suriya Rehman ${ }^{b}$, Firdos A. Khan, S. \\ Gunerd $^{\mathrm{d}}$,Sagar E. Shirsath ${ }^{\mathrm{e}}$,Abdulhadi Baykal ${ }^{\mathrm{f}}$
}

${ }^{a}$ Department of Biophysics, ${ }^{b}$ Department of Epidemic Disease Research, ${ }^{c}$ Department of Stem Cell Biology, ${ }^{f}$ Department of Nano-Medicine Research, Institute for Research and Medical Consultations (IRMC), Imam Abdulrahman Bin Faisal University, P.0. Box 1982, Dammam 31441, Saudi Arabia

dInstitute of Inorganic Chemistry, RWTH Aachen University, D-52074 Aachen/Germany

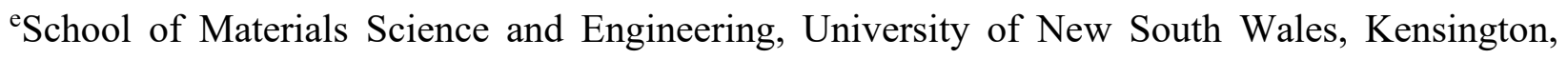
Sydney, NSW 2052, Australia

\begin{abstract}
Some new types of $\mathrm{Ce}^{3+}$ and $\mathrm{Dy}^{3+}$ co-doped manganese-zinc nanospinel ferrites (CDMZNSFs) of the form $\left(\mathrm{Mn}_{0.5} \mathrm{Zn}_{0.5}\right)\left[\mathrm{Fe}_{2-2 \mathrm{x}} \mathrm{Ce}_{\mathrm{x}} \mathrm{Dy}_{\mathrm{x}}\right] \mathrm{O}_{4}$ (with $0.0 \leq \mathrm{x} \leq 0.1$ ) were sonochemically produced and characterized. The structure, morphology, optical and magnetic behaviors of these NSFs were determined as a function of co-dopant $\left(\mathrm{Ce}^{3+}\right.$ and $\left.\mathrm{Dy}^{3+}\right)$ contents. In addition, the bactericidal (on the gram-positive and gram-negative bacterial strains) and anti-cancerous effectiveness of these NSFs were assessed. The cancer cells' growth inhibitory action of these NSFs was tested against both normal (HEK-293) and cancerous (HCT-116) human cells. The direct optical band gap
\end{abstract}


energies of the studied NSFs were ranged from 1.54 to $1.85 \mathrm{eV}$. The measured hysteresis loop and temperature-dependent magnetization of the NSFs disclosed a phase transformation from the superparamagnetic (SPM) at room temperature (RT) to ferromagnetic (FM) below the blocking temperature $\left(\mathrm{T}_{\mathrm{B}}\right)$. The saturation magnetization and $\mathrm{T}_{\mathrm{B}}$ were decreased with the increase in codopant contents. After $48 \mathrm{~h}$ of treatment of the cancerous cells with the NSFs, their population was significantly dropped as shown by the MTT assay, indicating the selective inhibition of the cancer cells growth by the proposed NSFs. Conversely, the non-cancerous cells (HEK-293) population remained unaffected. The $\mathrm{IC}_{50}$ values of the NSFs-treated cancerous cells (HCT-116) were in the range of $0.74-2.35 \mu \mathrm{g} / \mathrm{mL}$. The results of the MIC and MBC assays revealed the reasonable antibacterial efficacy (growth inhibitory activity) of these NSFs when tested against the E. coli and S. aureus bacterial strains. It is established that the proposed $\mathrm{Ce}^{3+} / \mathrm{Dy}^{3+}$ co-activated CDMZNSFs may be beneficial for the anti-cancerous and bactericidal applications.

Keywords: nanospinel ferrites; sonochemical; anti-cancerous; bactericidal; magnetic properties; morphology; cytotoxicity; inhibitory activity.

\section{Introduction}

Lately, the Mn-Zn spinel ferrites (MZSFs, the soft ferromagnetic ceramic materials) due to their exclusive electrical, magnetic and optical properties have widely been used in the communication, home appliances, computer, cores of inductors, transformers, recording heads, hyperthermia devices, cancer cells treatment, magnetic resonance imaging (MRI) and so forth. [1-4]. In-depth studies disclosed that all these unusual characteristics of the MZSFs are decided by preferred 
distributions of the $\mathrm{Fe}^{3+}$ and $\mathrm{Fe}^{2+}$ cations into the tetrahedral and octahedral sub-lattice sites in the crystal structure [3], where the syntheses techniques of these ferrites play a significant role.

The crystal unit cell of the MZSFs encloses sixty-four tetrahedral lattice positions (A-sites) and thirty-two octahedral lattice positions (B-sites), where the metal cations occupy eight A-lattice sites and sixteen B-lattice sites, leaving seventy-two positions vacant. Consequently, the unoccupied lattice sites in crystalline unit cells of the MZSFs can accommodate various metal ions such as the trivalent lanthanides, causing a modification in their structural, optical, and magnetic characteristics [5]. The present study is motivated by the possibilities where rare earth ions codoped new types of low dimensional MZSFs with improved traits can be composed for novel applications.

To fulfill the ever-increasing demand of the high-quality MZSFs, numerous syntheses strategies have been adopted such as the co-precipitation [6], polyol process [7], hydrothermal [8], solid-state reaction [9], sonochemical [10, 11], auto-combustion [12] and so on. Recent studies showed that using the ultrasonic waves at high intensity some good quality MZSFs nanostructures (doped and undoped) with customized properties can be achieved. Amongst all these techniques the sonochemical strategy is advantageous due to its ability to form nanocomposites of uniform sizes rapidly with less energy consumption and fast reaction rates $[13,14]$. On top, the sonochemical technique being relatively simple, accurate, and economic, it can produce contaminant-free Mn-Zn nanospinel ferrites (MZNSFs) at a large scale in short duration compared to the conventional approaches. In this view, we used this approach to prepare $\mathrm{Ce}^{3+} / \mathrm{Dy}^{3+}$ coactivated MZNSFs (CDMZNSFs).

According to Rezlucu et al. [15], the trivalent rare earth impurities due to their large ionic radii and exceptional $4 \mathrm{f}$ shell electronic configurations can be the excellent substituents in the lattice 
structures of the soft MZNSFs, thereby improving their structural, optical, magnetic and electrical traits. The rare earth ions substitutions in the MZNSFs leads to the development of a strong exchange coupling between the $4 \mathrm{f}$ and $3 \mathrm{~d}$ electrons, contributing to the significant magnetocrystalline anisotropy in the spinel structures and physical properties improvement [16-19]. In this perception, we used the sonochemical method to synthesize some new types of MZNSFs with $\mathrm{Ce}^{3+}$ and $\mathrm{Dy}^{3+}$ co-substitutions for the first time. As-prepared CDMZNSFs were characterized using diverse tools to determine the role of varying $\mathrm{Ce}^{3+}$ and $\mathrm{Dy}^{3+}$ contents on their structural, morphological, optical and magnetic features. In addition, the anticancer and anti-bacterial efficacy of the produced CDMZNSFs was tested against the human cells (normal HEK-293 and cancerous HCT-116) and bacterial strains (Escherichia coli and Staphylococcus aureus).

\section{Experimental}

2.1. Synthesis and characterizations of $\mathrm{Ce}^{3+}$ and $\mathrm{Dy}^{3+}$ co-doped MZNSFS

A series of MZNSFs co-activated with $\mathrm{Ce}^{3+} / \mathrm{Dy}^{3+}$ impurities were produced using the sonochemical route. First, the high purity chemical reagents (from Merck) of $\left[\mathrm{MnCl}_{2} \cdot 4 \mathrm{H}_{2} \mathrm{O}\right]$ (manganese II chloride), $\left[\mathrm{Zn}\left(\mathrm{NO}_{3}\right)_{2}\right]$ (zinc nitrate), $\left[\mathrm{Dy}\left(\mathrm{NO}_{3}\right)_{3} \cdot \mathrm{H}_{2} \mathrm{O}\right]$ (dysprosium III nitrate hydrate), $\left[\mathrm{Fe}\left(\mathrm{NO}_{3}\right)_{3} \cdot 9 \mathrm{H}_{2} \mathrm{O}\right]$ (Iron III nitrate nonahydrate) and $\left[\mathrm{Ce}\left(\mathrm{NO}_{3}\right)_{3} \cdot 6 \mathrm{H}_{2} \mathrm{O}\right]$ (cerium nitrate hexahydrate) were mixed in deionized water (DIW). The $\mathrm{pH}$ of the resultant mixture was adjusted to 11 via the addition of $2 \mathrm{M}$ of $\mathrm{NaOH}$ solution before being irradiated ultrasonically for $30 \mathrm{~min}$ (UZ SONOPULS Ultrasonic Homogenizer HD 2070 operated at the frequency of $20 \mathrm{kHz}$ and power of $70 \mathrm{~W}$ ). Next, the solution containing the product was rinsed using DIW followed by the drying at $60{ }^{\circ} \mathrm{C}$ for nearly $24 \mathrm{~h}$ to achieve the solid samples. Finally, samples were characterized at room temperature using different analytical instruments. 
The X-ray diffraction (XRD) analyses of the produced CDMZNSFs were performed (Rigaku Benchtop Miniflex X-ray Diffractometer operated with $\mathrm{Cu}-\mathrm{K} \alpha$ radiation) to determine their crystalline structures and phase compositions. The surface morphologies of the prepared NSFs were evaluated using the scanning electron microscopy (SEM, FEI Titan ST). The elemental compositions of the samples were studied using the energy dispersive X-ray (EDX) spectroscopy (attached to SEM). The shape and size distributions of the CDMZNSFs were recorded using a transmission electron microscope (TEM, FEI Morgagni 268). The UV-Visible diffuse reflectance spectra (in the wavelength range of $200-800 \mathrm{~nm}$ ) of the samples were obtained. The room temperature (RT, $300 \mathrm{~K}$ ) magnetic characteristics of the samples were examined by a vibrating sample magnetometer (VSM, Oxford $1.2 \mathrm{H}$ ) in the applied magnetic field $(\mathrm{H})$ range of $\pm 70 \mathrm{kOe}$. In addition, the zero-field-cooling (ZFC) and field-cooling (FC) magnetic behaviors were measured in the range of 300-2 K.

\subsection{Anticancer activities}

\subsubsection{In vitro cytotoxicity assay}

The colorectal carcinoma cells of human (HCT-116) were used to inspect the cancer cells inhibitory action of the as-prepared CDMZNSFs. Meanwhile, the normal (healthy) embryonic kidney cells of human (HEK-293) were used to assess the cytotoxicity of the CDMZNSFs. The earlier referred [13] protocols were used for the cells culture. The studied cells were cultivated at $37{ }^{\circ} \mathrm{C}$ in a carbon dioxide $\left(\mathrm{CO}_{2}\right)$ incubator inside the DMEM medium (Dulbecco's Modified Eagle's Medium) composed of the L-glutamine, fetal bovine serum, penicillin (antibiotic), selenium chloride and streptomycin. Upon reaching the confluence of $70-80 \%$, the MTT [3-(4,5dimethylthiazol-2-yl)-2,5-diphenyl tetrazolium bromide] assay (Molecules, New Zealand) was 
performed on the cultured cells to determine the anti-cancer viability of the proposed CDMZNSFstreated at various doses $(2.0$ to $40 \mu \mathrm{g} / \mathrm{mL})$ where the control group was devoid of NSFs. After treating the cells culture for a period of $48 \mathrm{~h}$, the culture media was isolated and supplemented with the MTT solution of concentration $10 \mathrm{mg} / \mathrm{mL}$ (Sigma-Aldrich, USA) followed by further incubation of the plates enclosing cultures. Again, the cells culture medium was isolated and every well was supplemented with dimethyl sulfoxide (DMSO) in which MTT created Formazan crystallites. Later, the plates enclosing the CDMZNSFs-treated cells culture were analyzed (at wavelength of $570 \mathrm{~nm}$ ) using the micro-plate readers (Bio-Rad Laboratories, USA). The mean and standard errors of both normal and CDMZNSFs-treated groups were scrutinized using the GraphPad Prism (GraphPad Software).

\subsubsection{Nuclear staining by 4',6-diamidino-2-phenylindole, DAPI) fluorescent dye}

The DAPI (4',6-diamidino-2-phenylindole) fluorescent dye $(1.0 \mu \mathrm{g} / \mathrm{mL})$ was used to stain the CDMZNSFs-treated cancer cells to discern their effects on the cell nuclei. The normal cells (HCT116) in group-I were treated with CDMZNSFs and group-II was not treated. After $48 \mathrm{~h}$ of treatments using the CDMZNSFs, both non-cancerous (HCT-116) and cancerous (HEK-293) human cells were treated with $4 \%$ of paraformaldehyde prepared in phosphate buffer saline (PBS). Thereafter, the cells' membranes were permeabilized using Triton X-100-PBS treatment for 5 min. Finally, the DAPI staining of the cells was conducted in the darkroom. The nuclear morphologies of the cells were examined via a confocal scanning microscope (Zeiss, Germany) [14]. 


\subsection{Bactericidal activities}

\subsubsection{Synthesis of inoculum and stock solutions}

To evaluate the antibacterial activities of the CDMZNSFs, the NSFs were homogenized using sterile distilled water to get the solution. The NSFs were added to the sterile Luria Bertaini (LB) broth at the concentration range of 16 to $0.5 \mathrm{mg} / \mathrm{mL}$. The inoculum of Escherichia coli (ATCC35218, gram-negative) and Staphylococcus aureus (ATCC29213, gram-positive) bacteria was prepared using the LB broth after the incubation at $35 \pm 2{ }^{\circ} \mathrm{C}$ for overnight. The cell densities $\left(2.5 \times 10^{6} \mathrm{CFUs} / \mathrm{mL}\right)$ of the freshly cultured bacterial strains were adjusted by the addition of sterile Luria Bertaini broth [15].

\subsubsection{Minimal inhibitory concentration (MIC)}

The MIC values of the prepared CDMZNSFs solutions were determined using the broth dilution method after supplementing the freshly adjusted bacterial inoculum (density of $2.5 \times 10^{5} \mathrm{CFU} / \mathrm{mL}$ ) with incubation in air for $24 \mathrm{~h}$ at $35 \pm 2{ }^{\circ} \mathrm{C}$. The solution without bacterial treatment was considered as the negative control. The MIC record was chosen as the minimal drug content at which no growth was visually seen, indicating the absence of turbidity.

\subsubsection{Minimum antibacterial concentration $(M B C)$}

After the MIC of evaluation of the CDMZNSFs solutions, the aliquot of suspension was withdrawn without causing any turbidity followed by the inoculation on freshly made Mueller Hinton Agar (MHA) plate with further incubation for $24 \mathrm{~h}$ at $35 \pm 2{ }^{\circ} \mathrm{C}$. The $\mathrm{MBC}$ of the drug was recorded as the lowermost content without bacterial cells or below 3 CFU on the MHA plate.

\subsubsection{Morphology characterization of CDMZNSFs-treated bacteria}


The effect of CDMZNSFs on the morphologies of the bacterial cells (gram positive and negative) was examined via SEM imaging. Both bacterial strains $\left(10^{6} \mathrm{CFU} / \mathrm{mL}\right)$ were treated at the concentration obtained as MIC value of the particular NSFs with the overnight incubation at $37 \pm 2{ }^{\circ} \mathrm{C}$ wherein the bacteria without NSFs treatment were taken as the control. Upon completing the incubation, the bacterial cells were centrifuged and washed repeatedly using the PBS. Thereafter, the bacterial cells were treated for $4 \mathrm{~h}$ using the glutaraldehyde (2.5\%) followed by the fixing via osmium tetroxide (1\%). Then, the resultant samples were rinsed and dried using ethanol at different concentrations. Next, the bacterial cells were put on the Al stubs and dried inside the desiccator followed by the Au coating for the SEM measurements [19].

\section{Results and discussion}

\subsection{Structural analyses of CDMZNSFs}

The formation of phases in the CDMZNSFs was observed via the XRD powder pattern as shown in Figure 1. The reflection planes for all the samples were found to belong to the pure single phase of the MZNSFs without any other phase of the metals oxides. The presence of intense diffraction peaks confirmed the presence of high crystallinity. The most intense peaks (311) of all the samples were broadened, indicating a decrease in the average crystallite size. The Rietveld refinement (Match3! fullproof) was used to estimate the lattice constant (a) and average crystallite size ranged from 8 to $18 \mathrm{~nm}$ (Table 1). The values of $a$ and unit cell volume (V) was found increase with the increase in the co-dopant $\left(\mathrm{Ce}^{3+} / \mathrm{Dy}^{3+}\right)$ concentration which was due to their larger ionic radii than the metal ions, generating a deformation in the spinel ferrite lattice to recompense the developing strain and stress [10]. 


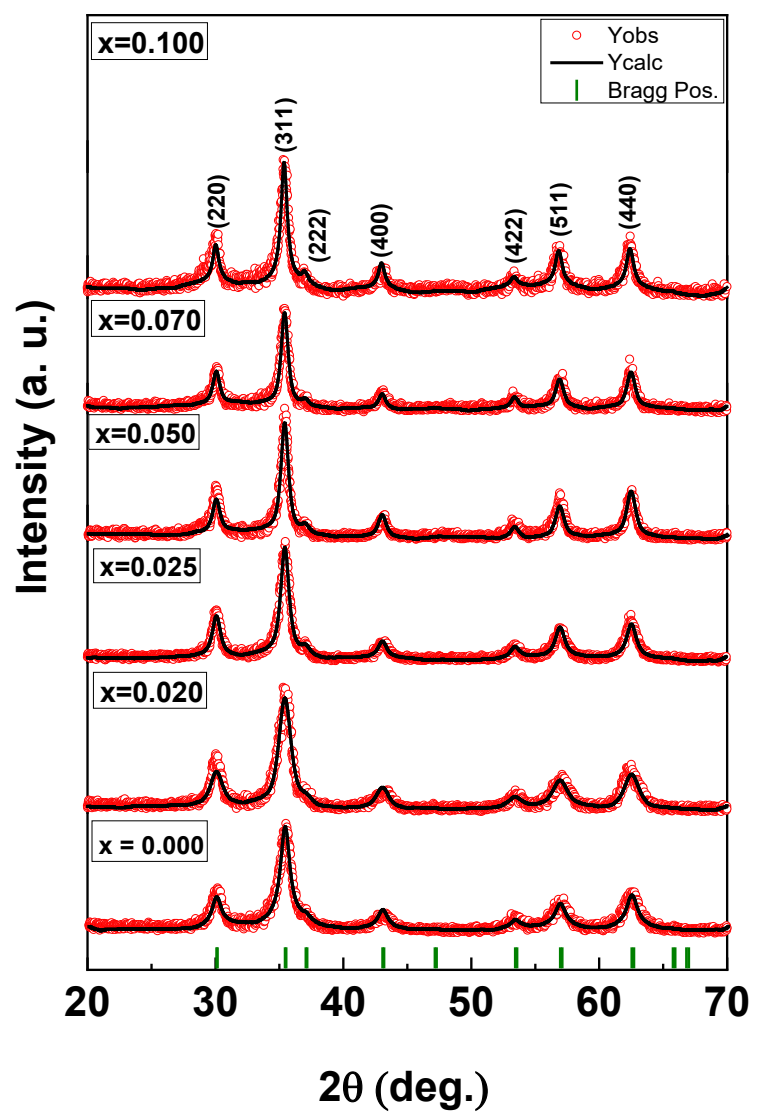

Figure 1. The XRD patterns of the studied CDMZNSFs.

Table 1. The structural properties of the studied CDMZNSFs.

\begin{tabular}{cccccc}
\hline $\mathbf{x}$ & $\boldsymbol{A}(\AA)$ & $\boldsymbol{V}(\AA)^{\mathbf{3}}$ & $\boldsymbol{D}_{\text {XRD }} \pm \mathbf{0 . 0 4}(\mathbf{n m})$ & $\chi^{2}$ & $\boldsymbol{R}_{\text {Bragg }}$ \\
\hline 0.000 & 8.3977 & 592.2151 & 18.5 & 1.2 & 13.2 \\
0.020 & 8.4018 & 593.0809 & 11.3 & 1.1 & 10.4 \\
0.025 & 8.4027 & 593.2673 & 10.8 & 1.3 & 12.7 \\
0.050 & 8.4053 & 593.8287 & 10.4 & 1.2 & 15.9 \\
0.070 & 8.4069 & 594.1721 & 9.6 & 1.0 & 13.9 \\
0.100 & 8.4167 & 596.2524 & 8.6 & 1.1 & 17.8 \\
\hline
\end{tabular}


The cations distribution in the CDMZNSFs crystalline unit cells was determined by analyzing the XRD data via the Bertaut technique as shown in Table 2 [20, 21]. The majority of the $\mathrm{Fe}^{3+}$ occupied the octahedral sites (B-sublattice position) with few at the tetrahedral sites (Asublattice position). Approximately $70-84 \%$ of the $\mathrm{Mn}^{3+}$ occupied the A-sites and $30-16 \%$ was distributed on the B-sites consistent with the preferential occupation at the tetrahedral sites [22]. The $\mathrm{Zn}^{3+}$ showed the strong preferential occupation towards the tetrahedral A-sites as expected. Meanwhile, the $\mathrm{Ce}^{3+} / \mathrm{Dy}^{3+}$ substituents preferentially occupied the octahedral B-sites only due to their larger ionic radii compared to the host metallic ions.

Table 2. Cations distribution in the CDMZNSFs unit cell.

\begin{tabular}{ccc}
\hline $\mathbf{x}$ & Tetrahedral position (A-sites) & Octahedral position (B-sites) \\
\hline 0.000 & $\mathrm{Mn}_{0.35} \mathrm{Zn}_{0.5} \mathrm{Fe}_{0.15}$ & $\mathrm{Mn}_{0.15} \mathrm{Fe}_{1.85}$ \\
0.020 & $\mathrm{Mn}_{0.35} \mathrm{Zn}_{0.5} \mathrm{Fe}_{0.15}$ & $\mathrm{Mn}_{0.15} \mathrm{Dy}_{0.02} \mathrm{Ce}_{0.02} \mathrm{Fe}_{1.81}$ \\
0.025 & $\mathrm{Mn}_{0.36} \mathrm{Zn}_{0.5} \mathrm{Fe}_{0.14}$ & $\mathrm{Mn}_{0.14} \mathrm{Dy}_{0.025} \mathrm{Ce}_{0.025} \mathrm{Fe}_{1.8}$ \\
0.050 & $\mathrm{Mn}_{0.38} \mathrm{Zn}_{0.5} \mathrm{Fe}_{0.12}$ & $\mathrm{Mn}_{0.12} \mathrm{Dy}_{0.05} \mathrm{Ce}_{0.05} \mathrm{Fe}_{1.78}$ \\
0.070 & $\mathrm{Mn}_{0.4} \mathrm{Zn}_{0.5} \mathrm{Fe}_{0.1}$ & $\mathrm{Mn}_{0.1} \mathrm{Dy}_{0.07} \mathrm{Ce}_{0.07} \mathrm{Fe}_{1.75}$ \\
0.100 & $\mathrm{Mn}_{0.42} \mathrm{Zn}_{0.5} \mathrm{Fe}_{0.08}$ & $\mathrm{Mn}_{0.08} \mathrm{Dy}_{0.05} \mathrm{Ce}_{0.05} \mathrm{Fe}_{1.72}$ \\
\hline
\end{tabular}

\subsection{Morphologies of CDMZNSFs}

Figure 2 displays the SEM micrographs of the prepared CDMZNSFs, which were comprised of the nonuniformly aggregated spherical nanocrystallites with the men size around $20 \mathrm{~nm}$. Figure 3 shows the TEM micrographs of the studied CDMZNSFs which were comprised of strong agglomerated nearly spherical nanocrystallites, supporting the SEM observations. Figure 4 
illustrates the EDX spectra of the achieved CDMZNSFs, verifying the appropriate elemental compositions (Mn, Zn, Dy, Fe, Ce and O) of the samples.

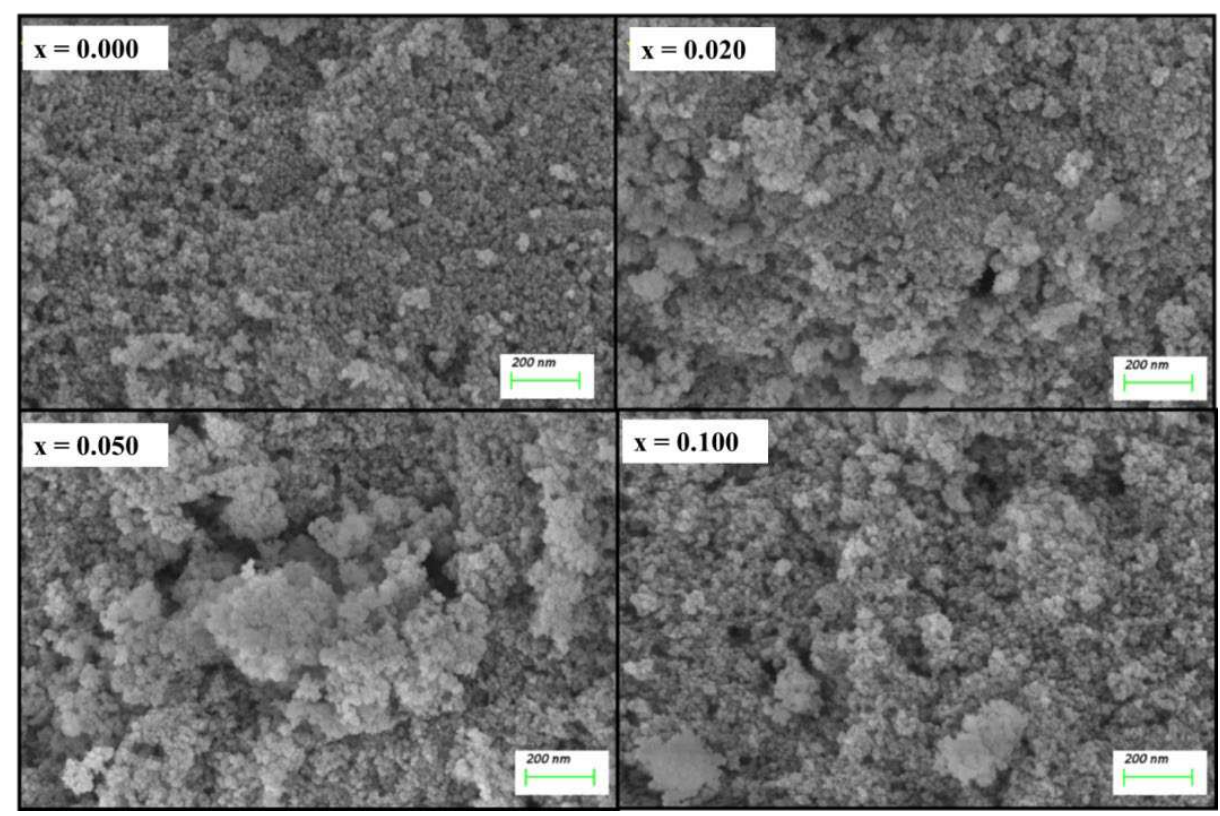

Figure 2. The SEM images of the synthesized CDMZNSFs.
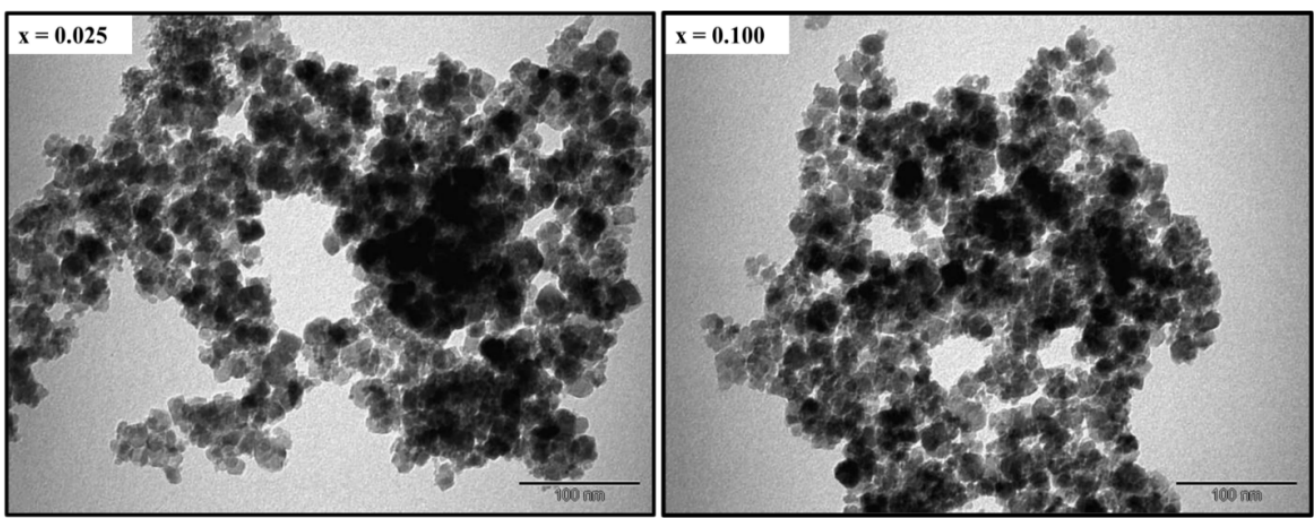

Figure 3. The TEM micrographs of the synthesized CDMZNSFs. 


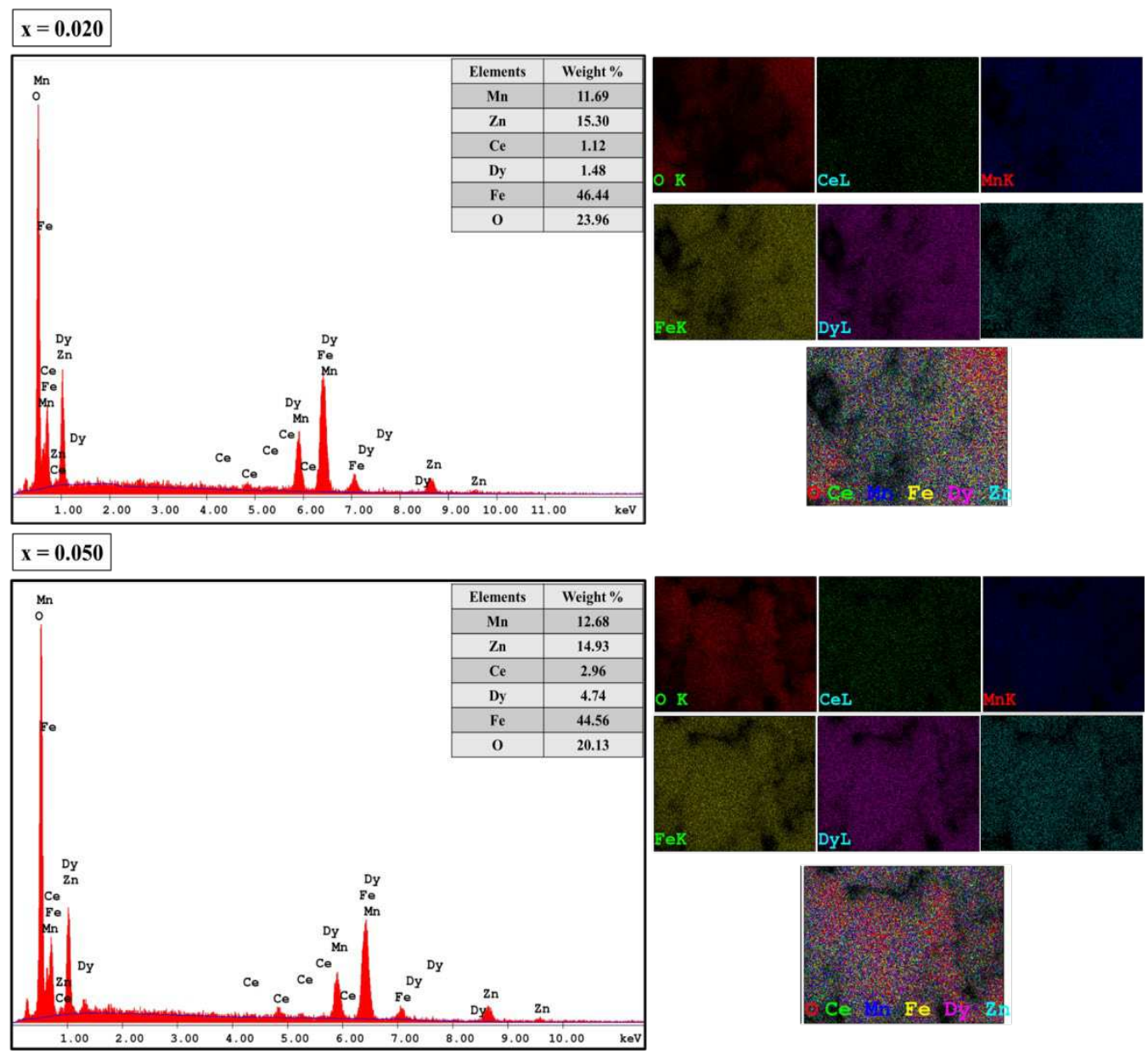

Figure 4. The EDX spectra and corresponding elemental maps of the synthesized CDMZNSFs (Inset: measured Weight $\%$ of various elements).

\subsection{Optical band gap energy}

Figure 5 shows the UV-Vis diffuse reflectance spectra of the synthesized CDMZNSFs wherein the UV edge data was used to estimate the optical band gap energies $\left(E_{\mathrm{g}}\right)$ of the samples [23, 24]. The DR\% values were further used to determine the optoelectronic properties of proposed CDMZNSFs. The spectral peak has appeared in the very narrow wavelength region between 200 - $500 \mathrm{~nm}$ with the DR values in the range of $13.40-15.70 \%$. The DR\% for all the NSFs showed a maximum of $28.8 \%$. 


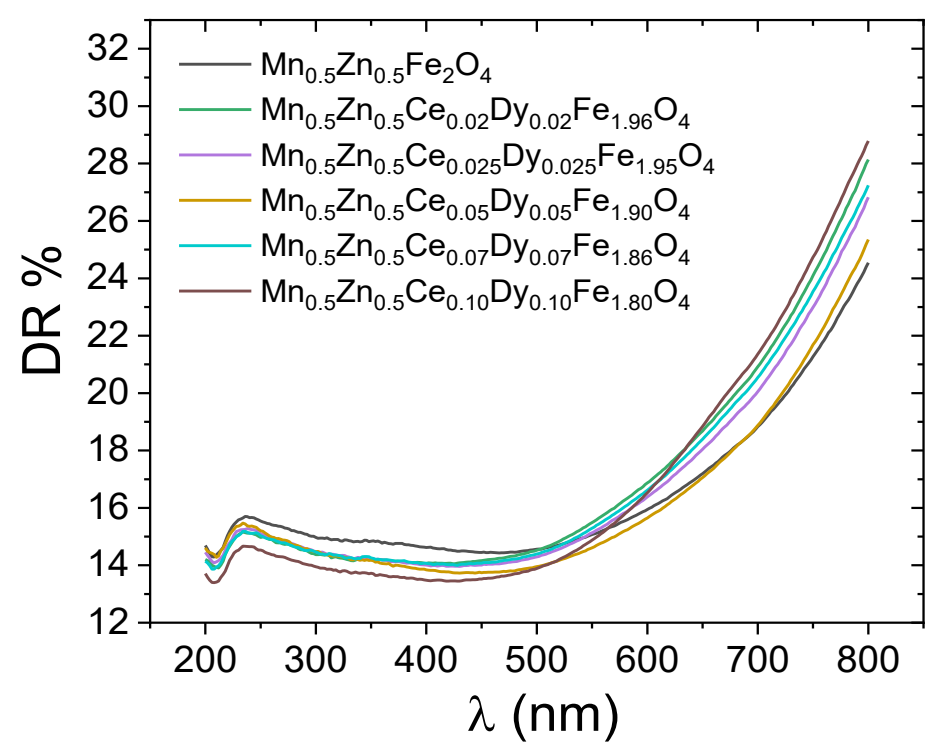

Figure 5. The diffuse reflectance spectra of the prepared CDMZNSFs.

The DR spectral data were analyzed using the radiative transfer model introduced by Kubelka-Munk (K-M). In this model, the function $F\left(R_{\infty}\right)$ is defined as [25]:

$$
F\left(R_{\infty}\right)=\frac{\left(1-R_{\infty}\right)^{2}}{2 R_{\infty}}=\frac{K}{S}=\frac{2.303 \varepsilon C}{S}
$$

where $R_{\infty}$ denotes the reflectance of the infinitely thick sample, $\varepsilon$ is the absorptivity, $K$ is the effective absorption coefficient, $S$ is the effective scattering coefficient and $\mathrm{C}$ is the analyte contents. The reflectance properties of the samples are characterized by the $K$ to $S$ ratios [25]. The photon energy $(h v)$ dependence of $F\left(R_{\infty}\right)$ can be approximated by the Tauc equation [26, 27]:

$$
\left(F\left(R_{\infty}\right) h v\right)^{n}=A\left(h v-E_{g}\right)
$$

where $\mathrm{A}$ is a constant and the exponent $n$ signifies the nature of electronic transition across the band gap (direct or indirect) with $\mathrm{n}=2$ for the direct transition. The Tauc plot $\left(F\left(R_{\infty}\right) h v\right)^{2}$ versus 
$(h v))$ was generated to evaluate the values of $E_{\mathrm{g}}$ from the linear part of extrapolated line to $\left(F\left(R_{\infty}\right) h v\right)^{2}=0$.

Figure 6 shows the Tauc plots of all the prepared CDMZNSFs. The estimated values of $E_{\mathrm{g}}$ for the $\mathrm{Dy}^{3+} / \mathrm{Ce}^{3+}$ co-doped MZNSFs were in the range of 1.74 to $1.77 \mathrm{eV}$, indicating the strong sensitiveness of the direct band gap energy of the NSFs on the co-dopant contents. The value of $E_{\mathrm{g}}$ for the undoped MZNSFs was found to be $1.65 \mathrm{eV}$ (lowest). All the prepared samples were semiconducting in nature. Some of the literature reports on the $\mathrm{Mn}_{0.5} \mathrm{Zn}_{0.5} \mathrm{Fe}_{2} \mathrm{O}_{4}$ NSFs prepared using hydrothermal and sonication assisted MW irradiation techniques revealed the corresponding $E_{\mathrm{g}}$ values of 1.98 and $1.99 \mathrm{eV}[28,29]$. In addition, other reports on the citric acid assisted sol-gel and thermal decomposition method grown $\mathrm{Mn}_{1-\mathrm{x}} \mathrm{Zn}_{\mathrm{x}} \mathrm{Fe}_{2} \mathrm{O}_{4}$ MZNSFs (where $\mathrm{x}$ from 0.2 to 0.8 ) showed the $E_{\mathrm{g}}$ values in between $1.86-2.80 \mathrm{eV}$ [30-32]. Present work is the first report of the $E_{\mathrm{g}}$ values for the $\mathrm{Dy}^{3+} / \mathrm{Ce}^{3+}$ co-substituted MZNSFs. 

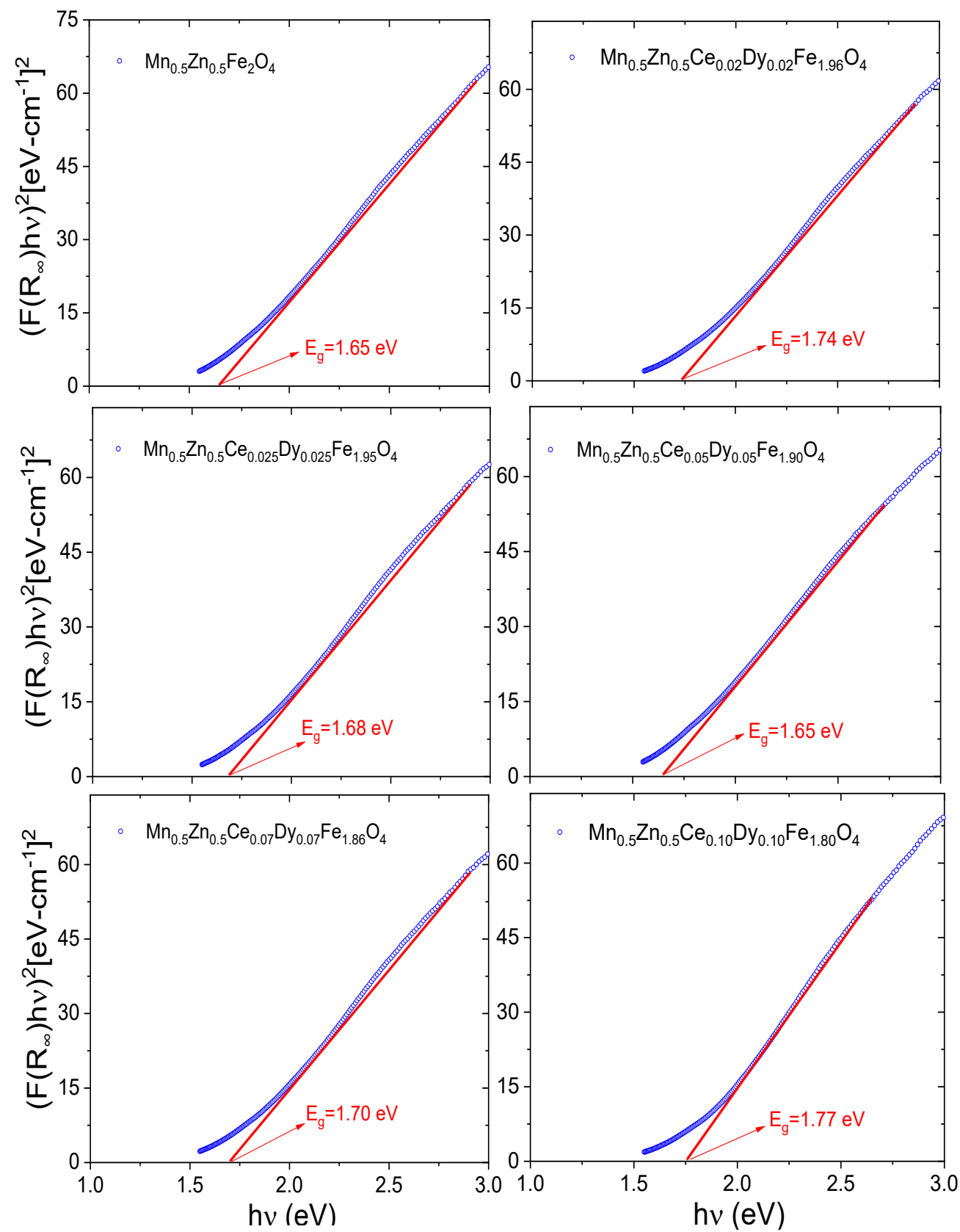

Figure 6. Tauc plots for all the obtained CDMZNSFs showing the estimated value of the optical band gap energies. 


\subsection{Magnetic features of CDMZNSFs}

\subsubsection{Hysteresis loop (M-H curves)}

Figure 7 displays the RT hysteresis loops of all the prepared CDMZNSFs, which revealed superparamagnetic (SPM) behaviors. The measured M-H curves of all the samples revealed Sshape without any coercivity $\left(\mathrm{H}_{\mathrm{c}}\right)$ and remanence $\left(\mathrm{M}_{\mathrm{r}}\right)$. This behavior was due to the nucleation of the tiny NSF crystallites that could easily orient via the thermal activation, thereby overcoming the magnetic anisotropy [33]. Essentially, the mean size of these crystallites was below the critical size (25 nm), thereby disclosing the predominant $S P M$ phase [34-36]. This result was consistent with the XRD analyses that yield DXRD values below $15 \mathrm{~nm}$ for various samples, confirming the crystallites sizes less than the critical limit (Table 1).

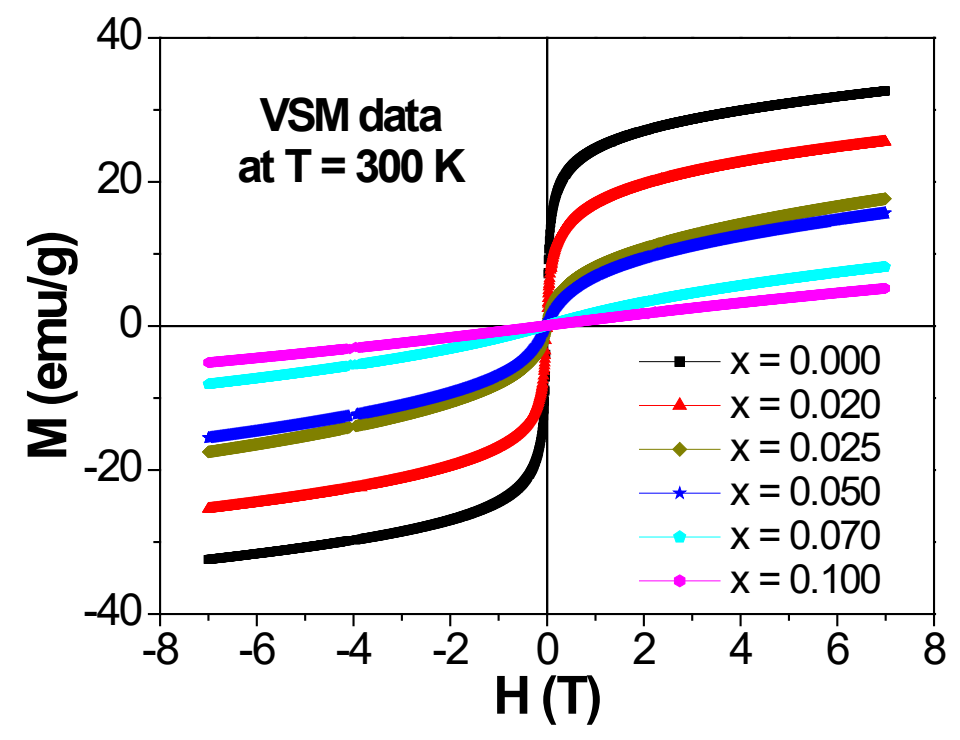

Figure 7. The RT hysteresis loops of all the obtained CDMZNSFs.

Since the magnetization of the prepared NSFs did not saturate completely (Figure 7) despite the high magnetic field, the law of approach to saturation (LAS) at the higher field regions was 
applied in the $\mathrm{M}$ against $1 / \mathrm{H}^{2}$ plot (Figure 8) for the selected undoped sample that enabled to estimate the values of the saturation magnetization $\left(\mathrm{M}_{\mathrm{s}}\right)[37,38]$.

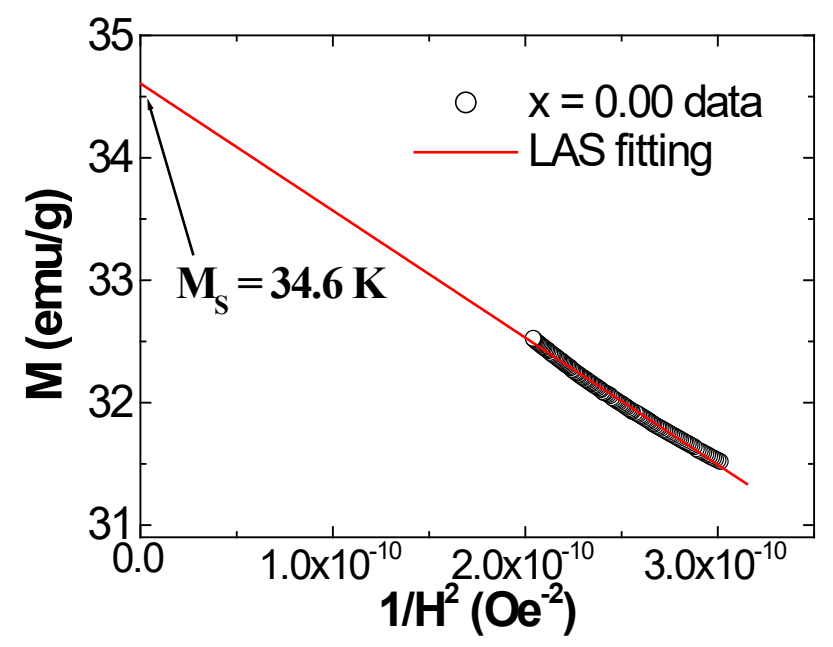

Figure 8. The $\mathrm{M}$ against $1 / \mathrm{H}^{2}$ plot of the undoped CDMZNSFs. The solid line shows the LAS fit.

Figure 9 illustrates the variations in the $M_{s}$ and magneton numbers $\left(n_{B}\right)$ as a function of the $\mathrm{Ce}^{3+} / \mathrm{Dy}^{3+}$ contents. The $n_{B}$ values were calculated via $[39,40]$ :

$$
n_{B}=\frac{\text { Moleculor weight } \times M_{S}}{5585}
$$

The value of $M_{s}$ and $n_{B}$ foe the undoped $(x=0.0)$ NSFs was $34.6 \mathrm{emu} / \mathrm{g}$ and $1.46 \mu_{\mathrm{B}}$, respectively. The observed value of the $M_{s}$ was lesser than that of its bulk conterpart ( $\approx 140 \mathrm{emu} / \mathrm{g}$ ) [41], which was mainly ascribed to the existence of the tinier crystallites that encountered the surface structural disorders, development of the magnetic inactive layers and spins canting [4244]. Nevertheless, the value of $\mathrm{M}_{\mathrm{s}}$ obtained by us is higher than those recorded in other MZNSFs produced using co-precipitation [45], low-temperature solid-state reaction [46], hydrothermal 
precipitation [47], evaporation and auto-combustion [48] and sol-gel combustion [49] methods. In comparison to the pristine specimen, the values of $M_{s}$ of the NSFs were decreased with the rise in $\mathrm{Ce}^{3+}$ and $\mathrm{Dy}^{3+}$ contents.

Generally, the magnetic characteristics can be affected by various factors including the changes in the crystallite morphology (size and shape), magnetic moment of the substituent ions, strength of the super-exchange interactions, disorder, inhomogeneities, etc. [35,50]. Several studies acknowledged the proportionality in the evolutions of the $M_{s}$ and $D_{X R D}$ magnitudes [35,50]. Basically, the values of $M_{s}$ were increased with the enlargement of the crystallites dimension and vice versa. As aforementioned, the values of $D_{X R D}$ were reduced with the increase in $\mathrm{Ce}^{3+}$ and $\mathrm{Dy}^{3+}$ contents, supporting the similar trend in the variation of $M_{s}$. Furthermore, the differences in the ionic radii of $\mathrm{Ce}^{3+}(1.01 \AA), \mathrm{Dy}^{3+}(0.91 \AA)$ and $\mathrm{Fe}^{3+}(0.64 \AA)$ were responsible for such magnetic responses of the proposed NSFs. These dissimilarities in ionic radii have a tendency to induce the structural disorder, lattice strains and alteration in the electronic states into the prepared NSFs [51]. Additionally, the reduction in the $n_{B}$ values signifies an weakening in the super-exchange coupling $[52,53]$. The variation of the $n_{B}$ as function of the $\mathrm{Ce}^{3+}$ and $\mathrm{Dy}^{3+}$ contents showed similar trend as that of $M_{s}$, indicating the destabilization of the super-exchange interactions.

To further elucidate the magnetic behavior of the produced NSFs, the Nèel model was utilized. The net magnetization (M) of the NSFs in terms of the A $\left(M_{A}\right)$ and $\mathrm{B}\left(M_{B}\right)$ sublattice magnetizations yields:

$$
M=M_{B}-M_{A}
$$

The magnetic moment of $\mathrm{Mn}^{2+}, \mathrm{Zn}^{2+}, \mathrm{Fe}^{3+}, \mathrm{Ce}^{3+}$ and $\mathrm{Dy}^{3+}$ are 3.9, 0, 5, 2.5 and $10.5 \mu_{\mathrm{B}}$, respectively. First, by assuming only the replacement of some of the $\mathrm{Fe}^{3+}\left(5 \mu_{\mathrm{B}}\right)$ by the $\mathrm{Dy}^{3+}(10.5$ $\left.\mu_{\mathrm{B}}\right)$ an enhancement in the magnetization can be seen, but this is not the case here. In this study, 
the value of $M_{s}$ was decreased with the rise in the substitution ions content. This could be due to the further substitution of some of the $\mathrm{Fe}^{3+}$ by the $\mathrm{Ce}^{3+}$ with $2.5 \mu_{\mathrm{B}}$. The obtained trend in magnetization can be explained based on the distribution of different cations (occupation of $\mathrm{Mn}^{2+}$, $\mathrm{Zn}^{2+}$ and $\mathrm{Fe}^{3+}$ in both $\mathrm{A}$ and $\mathrm{B}$ site) in the ferrite crystal structure. The cations distribution in the current study showed that the $\mathrm{Ce}^{3+}$ preferentially to occupied only the B site, whereas the $\mathrm{Dy}^{3+}$ could occupy both positions (A and B-sites). Consequently, the magnetic moment in the A site was increased with the rise in $\mathrm{Dy}^{3+}$ and $\mathrm{Ce}^{3+}$ contents, thereby reducing the net magnetization of the proposed CDMZNSFs.

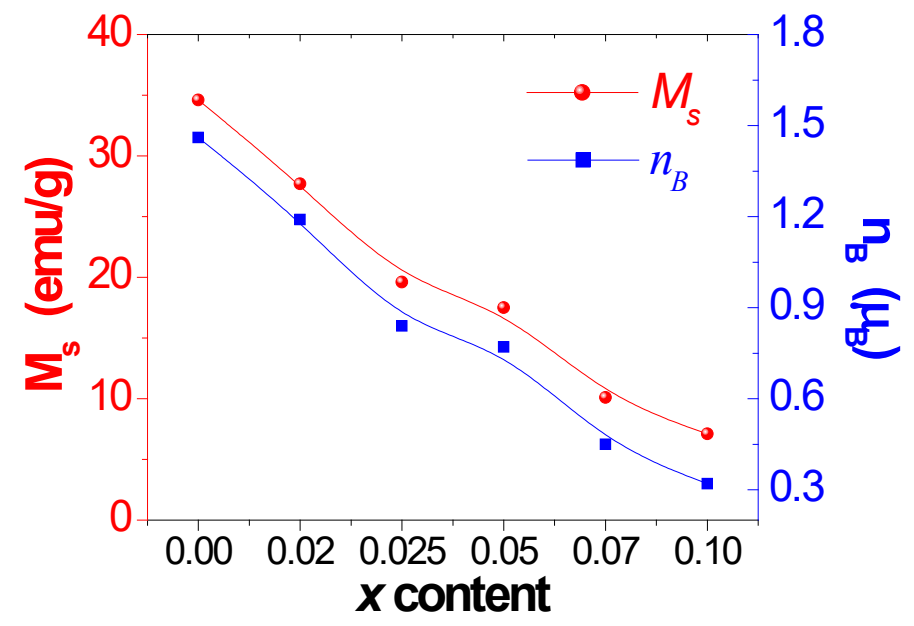

Figure 9. Dependence of $\mathrm{M}_{\mathrm{s}}$ and $n_{B}$ on the co-substituents $\left(\mathrm{Ce}^{3+} / \mathrm{Dy}^{3+}\right)$ contents.

\subsubsection{Magnetization against temperature (M-T)}

Figure 10 shows the measured $\mathrm{ZFC}$ and $\mathrm{FC}$ curves (M against $\mathrm{T}$ variation) of the produced CDMZNSFs, which revealed a characteristic splitting and irreversibility as expected for the ferrites. In comparison to undoped sample, both $\mathrm{M}_{\mathrm{ZFC}}$ and $\mathrm{M}_{\mathrm{FC}}$ values were significantly decreased with the increase in $\mathrm{Dy}^{3+}$ and $\mathrm{Ce}^{3+}$ contents which supported the $\mathrm{M}-\mathrm{H}$ results. In addition, the $\mathrm{M}_{\mathrm{FC}}$ 
values were increased with the decrease in the temperature and reached to a maximum value before being dropped. Generally, the SPM materials disclose a continuous increase in in the $\mathrm{M}_{\mathrm{FC}}$ values with the increase in T [54]. Conversely, the observed plateau-like behavior or a decrement in the $\mathrm{M}_{\mathrm{FC}}$ value at lower temperatures indicated a magnetic phase transformation. Several reports suggested that the emergence of the peak at a particular temperature in the $\mathrm{M}_{\mathrm{ZFC}}$ versus $\mathrm{T}$ curves may be associated to the blocking temperature $\left(T_{B}\right)$. The magnetic system undergoes a phase transformation from the SPM (above $T_{B}$ ) to the ferromagnetic (FM) state (under $T_{B}$ ). In the present case, various NSFs disclosed a wide peak at $T_{B}$ in the MzFC against $\mathrm{T}$ curves, indicating a SPM to FM phase transition below $T_{B}$. It is affirmed that the value of $T_{B}$ is significantly influenced by the $\mathrm{Ce}^{3+} / \mathrm{Dy}^{3+}$ contents. Indeed, the value of $\mathrm{T}_{\mathrm{B}}$ was shifted from $79.5 \mathrm{~K}$ (for the undoped NSFs) to lower the temperatures with the rise in co-substituents $\mathrm{Ce}^{3+}$ and $\mathrm{Dy}^{3+}$ contents. The values of $\mathrm{T}_{\mathrm{B}}$ for the CDMZNSFs containing $0.00,0.02,0.025,0.05,0.07$, and 0.10 of $\mathrm{Ce}^{3+} / \mathrm{Dy}^{3+}$ were discerned to be $79.5,76.9,74.8,74.1,57.4$ and $45.3 \mathrm{~K}$, respectively.

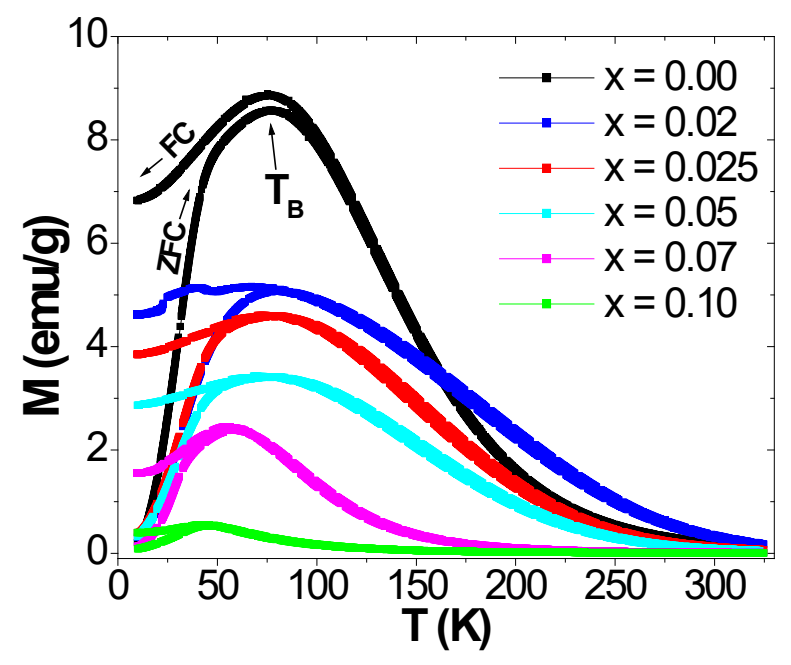

Figure 10. ZFC-FC magnetizations of the prepared CDMZNSFs at the applied magnetic field of 100 Oe. 


\subsection{Anticancer effectiveness}

The anticancer activities of the produced CDMZNSFs on the human cells were evaluated via the MTT assay where the inhibitory concentration ( $\left.\mathrm{IC}_{50}\right)$ was measured. The $48 \mathrm{~h}$ post-treated HCT116 (cancerous) cells by the CDMZNSFs revealed appreciable inhibition activities, confirming their anti-cancerous benefits for the drug formulation. Table 3 shows the values of $\mathrm{IC}_{50}$ obtained by treating the cancel cells by different CDMZNSFs. To verify the cytotoxicity of the proposed CDMZNSFs, they were tested on the healthy human kidney cells (HEK-293). The $48 \mathrm{~h}$ posttreated HEK-293 (noncancerous) cells by the CDMZNSFs did not show any cytotoxic effect, indicating the feasibility of using these NSFs for cancer treatments without damaging the healthy cells.

Table 3. The measured $\mathrm{IC}_{50}$ values of the CDMZNSFs-treated HCT-116 (cancer) and HEK-293 (normal) human cells.

\begin{tabular}{|c|c|c|}
\hline $\mathbf{x}$ & $\begin{array}{c}\text { IC50 }(\boldsymbol{\mu g} / \mathbf{m L}) \\
\text { for } \mathbf{H C T}-116\end{array}$ & $\begin{array}{c}\text { IC50 }(\boldsymbol{\mu g} / \mathbf{m L}) \\
\text { for HEK-293 }\end{array}$ \\
\hline 0.000 & 0.74 & Zero inhibitory action \\
\hline 0.020 & 0.85 & Zero inhibitory action \\
\hline 0.025 & 0.84 & Zero inhibitory action \\
\hline 0.050 & 0.60 & Zero inhibitory action \\
\hline 0.070 & 0.45 & Zero inhibitory action \\
\hline 0.100 & 2.35 & Zero inhibitory action \\
\hline
\end{tabular}




\subsubsection{Cytotoxicity due to nuclear disintegration}

Figure 11 shows the CDMZNSFs-treated HCT-116 (cancer) cells and untreated cells (control group) morphologies after staining by DAPI for $48 \mathrm{~h}$. The control (Figure 11 (a)) did not reveal any inhibition activity. However, the CDMZNSFs-treated (Figure 11 (a) with the dose of 0.74 $\mu \mathrm{g} / \mathrm{mL}$ and Figure 11 (b) with the dose of $2.35 \mu \mathrm{g} / \mathrm{mL}$ ) HCT-116 (cancer) cells exhibited stronger inhibition action (indicated by arrow heads at $200 \times$ magnified) compared to the control group, confirming the nuclear staining-mediated loss of the cells.
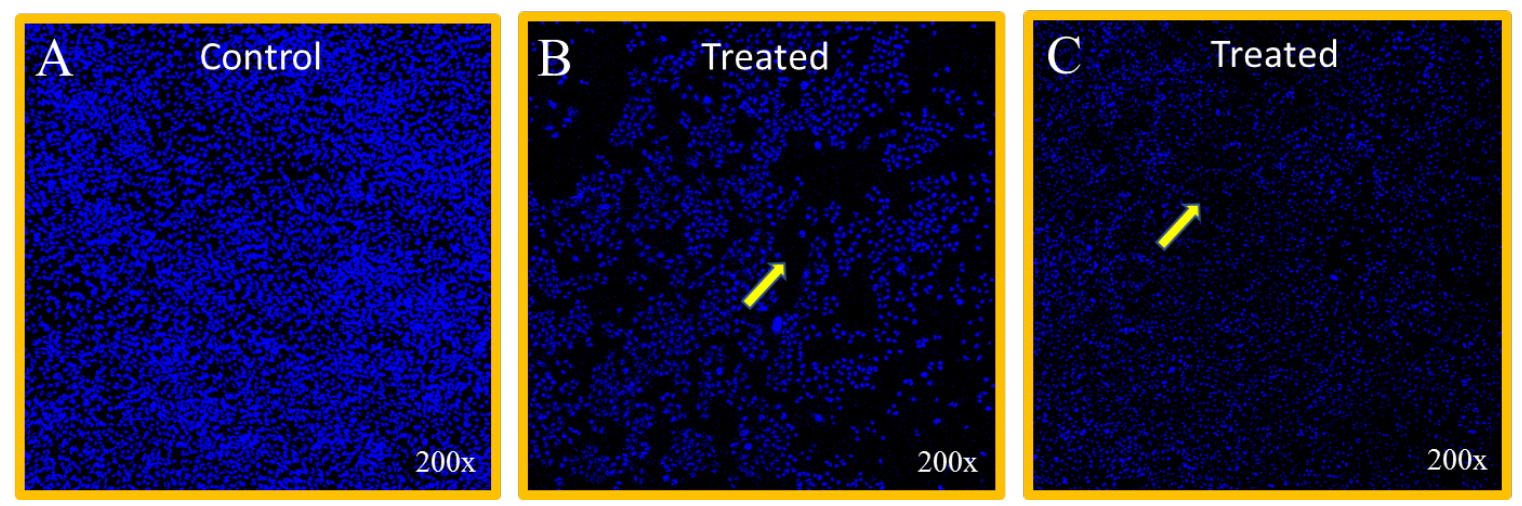

Figure 11. The cell morphologies after DAPI staining (48 h) for the (a) untreated control group, (b) CDMZNSFs-treated ( $\mathrm{x}=0.00$ dose of $0.74 \mu \mathrm{g} / \mathrm{mL}$ ) cancer cells and (c) CDMZNSFs-treated ( $\mathrm{x}=0.10$ dose of $2.35 \mu \mathrm{g} / \mathrm{mL}$ ) cancer cells. Arrow heads shows the nuclear staining-mediated decay of the cells.

Present findings indicated that the proposed CDMZNSFs were selective in targeting the colon cancer cells without causing any damage to the noncancerous (normal or healthy) cells, suggesting their prospects for cancer therapeutic purposes. It was acknowledged that the magnetic nanoparticles are beneficial for the drugs delivery and other diagnoses [55]. Furthermore, some reports showed the death of cancerous cells with strong nuclear fragmentations and disintegrations 
when treated with magnetic nanoparticles, indicating their promise for cancer therapy [56, 57]. In short, the proposed CDMZNSFs revealed strong inhibitory actions on the cancerous cells, indicating their potential for cancer cures.

\subsection{Bactericidal activity}

\subsubsection{MIC/MBC evaluation}

The bactericidal efficacy of the as-synthesized CDMZNSFs (at various concentrations from 16 to $0.5 \mathrm{mg} / \mathrm{mL}$ ) against the $E$. coli and $S$. aureus bacteria was assessed by the values of MIC/MBC. The values of MIC/MBC for the CDMZNSFs-treated E. coli bacterial strains were discerned to be $8 / 16($ for $\mathrm{x}=0.00), 8 / 16($ for $\mathrm{x}=0.02), 8 / 16($ for $\mathrm{x}=0.025), 8 / 16($ for $\mathrm{x}=0.05), 4 / 16($ for $\mathrm{x}=0.07)$ and $4 / 8 \mathrm{mg} / \mathrm{mL}$ (for $\mathrm{x}=0.1$ ) as shown in Figure 12(a). The values of MIC/MBC for the CDMZNSFstreated $S$. aureus bacterial strains were observed to be $8 / 16$ (for $\mathrm{x}=0.00$ ), $8 / 16$ (for $\mathrm{x}=0.02$ ), $8 / 16$ (for $\mathrm{x}=0.025$ ), $8 / 16$ (for $\mathrm{x}=0.05$ ), $8 / 16$ (for $\mathrm{x}=0.07$ ) and $4 / 8 \mathrm{mg} / \mathrm{mL}$ (for $\mathrm{x}=0.1$ ) as shown in Figure 12(b). These MIC/MBC indicated the possibility of bactericidal improvement by controlling the $\mathrm{Ce}^{3+}$ and $\mathrm{Dy}^{3+}$ doping contents in the MZNSFs with the lowest one for $\mathrm{x}=0.1$. The antibacterial activity of the CDMZNSFs-treated gram negative bacteria was slightly higher than the one obtained for the gram positive bacterial strains which was ascribed to the compositional dissimilarities in their cells wall structures $[58,59]$. The bactericidal potential of various metal ions doped $\mathrm{Zn}, \mathrm{Cu}, \mathrm{Ni}$ and $\mathrm{Mn}$ nanoparticles reported in the literature [60,61] are good agreement with the present findings on CDMZNSFs, indicating their prospects for sundry biomedical applications. 


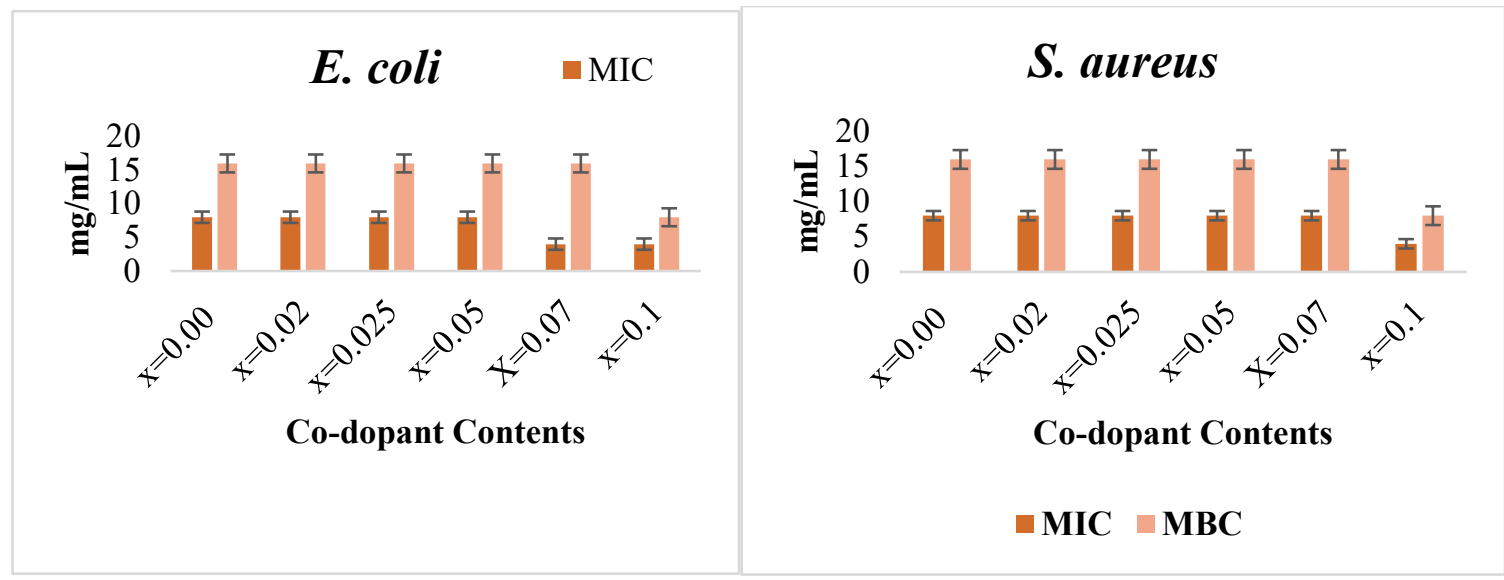

(a)

(b)

Figure 12. The measured values of MIC/MBC for the CDMZNSFs-treated (a) E.coli, and (b) $S$. aureus bacteria.

\subsubsection{Morphologies of CDMZNSFs-treated bacteria}

The structural alteration in the E. coli and $S$. aureus caused by the CDMZNSFs treatment were examined via SEM imaging. The untreated E. coli and $S$. aureus bacterial cells were observed to be normal rod and spherical in shapes with uniform cell surface, respectively (Figure 13 (a). E. coli and $S$. aureus cells treated with $\mathrm{x}=0.00$ and $\mathrm{x}=0.02$ showed a mild damage. However, when treated with the CDMZNSFs of $x=0.025$ and $x=0.05$, the cells were found to be significantly affected (Figure $13 \mathrm{~b}, \mathrm{c}, \mathrm{d}, \mathrm{e}$ ). Again, after treating with the CDMZNSFs of $\mathrm{x}=0.07$ and $\mathrm{x}=0.1$, the cells were observed to be severely damaged with a smaller number of cells visible. This damage of the cells with distortion and deformation of the cell surface clearly indicated the loss of integrity of membrane due to the impact of the CDMZNSFs (Figure $13 \mathrm{e}, \mathrm{f}$ ). The cells damage and count of the $E$. coli bacteria was lower compared to the $S$. aureus, which are due to their dissimilar structural compositions of the cells wall $[61,62]$. It is affirmed that the morphogenesis of both gram negative and gram positive bacteria were appreciably affected by the CDMZNSFs treatment. This 
observation was attributed to the efficient attachment and penetration of the CDMZNSFs through the cell membrane, thereby destructing the bacterial cells.
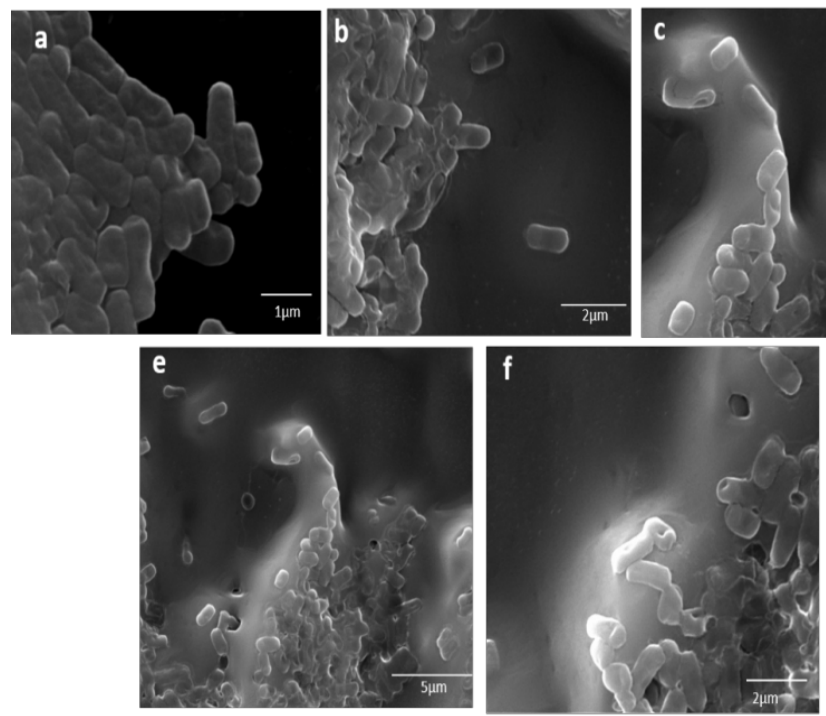

(a1)
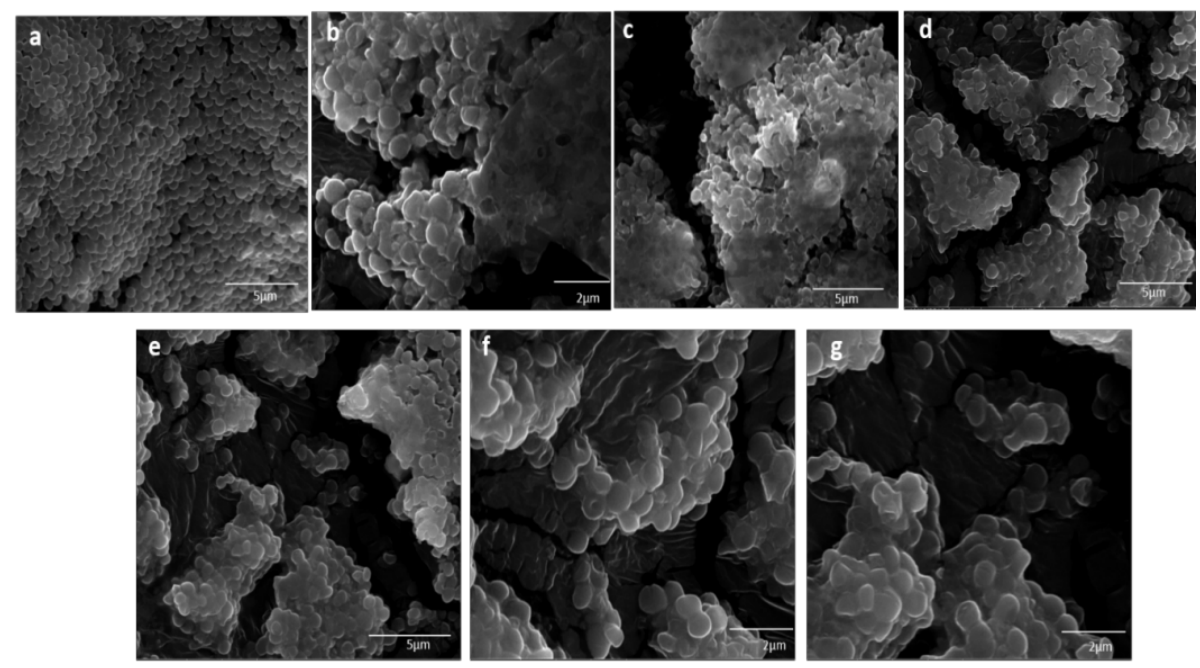

(b1)

Figure 13. SEM micrographs of the CDMZNSFs-treated bacteria (a1) E. coli (b1) S. aureus. a) untreated cells(control), b) $\mathrm{x}=0.00$, c) 0.02, d) 0.025, e) 0.05, f) 0.07 and g) 0.01 .

\section{Conclusion}


This paper evaluated the structure, morphology, optical, magnetic, bactericidal, and anticancer traits of the new series of $\mathrm{Ce}^{3+} / \mathrm{Dy}^{3+}$ co-activated CDMZNSFs for the first time. These samples were sonochemically prepared and analyzed in-dept. The produced CDMZNSFs revealed appreciable bactericidal (when tested against E. coli and S. aureus bacteria) and anti-cancerous (tested against cancerous HCT-116 human cells) efficacy. The cancer cells growth was significantly inhibited (with $\mathrm{IC}_{50}$ values ranged from $0.74-2.35 \mu \mathrm{g} / \mathrm{mL}$ ) due to the CDMZNSFs treatment (for $48 \mathrm{~h}$ ), whereas the normal HEK-293 cells growth was not affected. On top, these CDMZNSFs did not show any cytotoxicity. The grown NSFs manifested a SPM to FM phase transition below $T_{B}$, useful for practical purposes. Both $M_{S}$ and $T_{B}$ values were reduced with the rise in $\mathrm{Ce}^{3+} / \mathrm{Dy}^{3+}$ contents. The MTT assay of the CDMZNSFs-treated cancerous cells disclosed a notable drop in their population, indicating the selective inhibition (DAPI staining for $48 \mathrm{~h}$ ) of the cancer cells growth by the prepared NSFs. However, the populations of the HEK-293 cells were not affected by the CDMZNSFs treatment. The MIC and MBC displayed realistic bactericidal activity of these NSFs against gram negative and gram positive bacterial strains. The observed improvements in various properties of the CDMZNSFs as ascribed to the $\mathrm{Ce}^{3+} / \mathrm{Dy}^{3+}$ co-activation assisted change in the magnetic moments, crystallites size and shape variations, and cations distribution in the lattice unit cells. It was shown that by adjusting the $\mathrm{Ce}^{3+} / \mathrm{Dy}^{3+}$ co-substituent contents the overall properties of the CDMZNSFs can be tailored. It is established that the proposed $\mathrm{Ce}^{3+} / \mathrm{Dy}^{3+}$ co-activated CDMZNSFs can be beneficial for the anti-cancerous and bactericidal applications. In addition, the proposed CDMZNSFs composition may contribute to the development of biomedical and pharmaceutical applications. It is worth to perform more careful studies to validate these disclosures and claim, which is underway.

\section{Acknowledgment}


This study is supported by the Institute for Research and Medical Consultations (Project application No. 2018-IRMC-S-2) and by the Deanship for Scientific Research (Project application No. 2020-164-IRMC) of Imam Abdulrahman Bin Faisal University (IAU - Saudi Arabia).

\section{References}

[1] P. Hu, H. B. Yang, D.A. Pan, H. Wang, J.J. Tian, S.G. Zhang, X.F. Wang, A.A. Volinsky, Heat treatment effects on microstructure and magnetic properties of $\mathrm{Mn}-\mathrm{Zn}$ ferrite powders, J. Magn. Magn. Mater. 322 (2010) 173-177.

[2] Q. Xing, Z. Peng, C.Wang, Z. Fu, X. Fu, Doping effect of $\mathrm{Y}^{3+}$ ions on the microstructural and electromagnetic properties of Mn-Zn ferrites, Physica B: Condensed Matter 407(3) (2012) $388-392$.

[3] M.A. Ahmed, N. Okasha, M.M. El-Sayed, Enhancement of the physical properties of rareearth-substituted Mn-Zn ferrites prepared by flash method, Ceram. Int. 33 (2007) 49-58.

[4] K. Parekh, R.V. Upadhyay, L. Belova, K.V. Rao, Ternary monodispersed $\mathrm{Mn}_{0.5} \mathrm{Zn}_{0.5} \mathrm{Fe}_{2} \mathrm{O}_{4}$ ferrite nanoparticles: preparation and magnetic characterization, Nanotechnology 17 (2006) $5970-5975$.

[5] S. Modak, M. Ammar, F. Mazaleyrat, S. Das, and P. K. Chakrabarti, XRD, HR-TEM and magnetic properties of mixed spinel nanocrystalline Ni-Zn-Cu-ferrite, J. Alloys Compd. 473 (2009) 15-19.

[6] P. Mathur, A. Thakur, M. Singh, Study of low-temperature sintered nano-crystalline Mn-CuZn ferrite prepared by co-precipitation method, Modern Physics Letters B 21 (2007) 14251430. 
[7] J. Topfer, A. Angermann, Nanocrystalline magnetite and Mn-Zn ferrite particles via the polyol process: synthesis and magnetic properties, Mater. Chem. Phys. 129 (2011) 337-342

[8] S. Akhtar, S. Rehman, Munirah A. Almessiere, Firdos A. Khan, Y. Slimani, A. Baykal, Synthesis of $\mathrm{Mn}_{0.5} \mathrm{Zn}_{0.5} \mathrm{Sm}_{\times} \mathrm{Eu}_{\mathrm{x}} \mathrm{Fe}_{1.8-2 \mathrm{x}} \mathrm{O}_{4}$ nanoparticles via hydrothermal approach induced anti-cancer and anti-bacterial activities, Nanomaterials 9(11) (2019) 1635.

[9] G. Kogias, V.T. Zaspalis, Temperature stable MnZn ferrites for applications in the frequency region of $500 \mathrm{kHz}$, Ceram. Int. 42 (2016) 7639-7646

[10] M.A. Almessiere, A.V. Trukhanov, F.A. Khan, Y. Slimani, N. Tashkandi, V.A. Turchenko, T.I. Zubar, D.I. Tishkevich, S.V. Trukhanov, L.V. Panina, A. Baykal, Correlation between microstructure parameters and anti-cancer activity of the $\left[\mathrm{Mn}_{0.5} \mathrm{Zn}_{0.5}\right]\left(\mathrm{Eu}_{\mathrm{x}} \mathrm{Nd}_{\mathrm{x}} \mathrm{Fe}_{2-2 \mathrm{x}}\right) \mathrm{O}_{4}$ nanoferrites produced by modified sol-gel and ultrasonic methods, Ceram. Int. 46 (2020) $7346-7354$.

[11] S. Rehman, M.A. Almessiere, A.D. Korkmaz, N. Natashakandi, Y. Slimani, A. Baykal, Synthesis and biological characterization of $\mathrm{Mn}_{0.5} \mathrm{Zn}_{0.5} \mathrm{Eu}_{x} \mathrm{Dy}_{\mathrm{x}} \mathrm{Fe}_{1.8-2 \mathrm{x}} \mathrm{O}_{4}$ nanoparticles by sonochemical approach, Materials Science \& Engineering C 109 (2020) 110534

[12] A. Baykal, S. Esir, A. Demir, S. Güner, Magnetic and optical properties of $\mathrm{Cu}_{1-\mathrm{x}} \mathrm{Zn}_{\mathrm{x}} \mathrm{Fe}_{2} \mathrm{O}_{4}$ nanoparticles dispersed in a silica matrix by a sol-gel auto-combustion method, Ceram. Int. $41(2015) 231-239$

[13] S. Asgharzadehahmadi, A. Abdul Raman, R. Parthasarathy, B. Sajjadi, Sonochemical reactors: Review on features, advantages and limitations, Renewable and Sustainable Energy Reviews 63 - May 2016. 
[14] D.V. Pinjari, A.B. Pandit, Room temperature synthesis of crystalline $\mathrm{CeO}_{2}$ nanopowder: Advantage of sonochemical method over conventional method, Ultrasonics Sonochemistry 18(5) (2011) 1118-1123.

[15] N. Rezlescu, E. Rezlescu, D.P. Popa, L. Rezlescu, Effects of rare-earth oxides on physical properties of Li-Zn ferrite, J. Alloys Comp. 275-277 (1998) 657

[16] R. Islam, M.A. Hakim, M.O. Rahman, H. Narayan Das, M.A. Mamun, Study of the structural, magnetic and electrical properties of Gd-substituted Mn-Zn mixed ferrites, J. Alloys Compd. 559 (2013) 174-180.

[17] J. Song, L. Wang, N. Xu, Q. Zhang, Microwave electromagnetic and absorbing properties of $\mathrm{Dy}^{3+}$ doped MnZn ferrites, J. Rare Earths 28(3) (2010) 451-455.

[18] M.A. Almessiere, A. Demir Korkmaz, Y. Slimani, M. Nawaz, S. Ali, A.Baykal, Magnetooptical properties of rare earth metals substituted Co-Zn spinel nanoferrites, Ceram. Int. 45 (2019) 3449-3458.

[19] E.E. Ateia, M.K. Abdelmaksoud, M.M. Arman, A.S. Shafaay, Comparative study on the physical properties of rare-earth-substituted nano-sized $\mathrm{CoFe}_{2} \mathrm{O}_{4}$, Appl. Physics A 126 (91) (2020).

[20] S.E. Shirsath, M. L. Mane, Y. Yasukawa, X. Liu, A. Morisako, Chemical tuning of structure formation and combustion process in $\mathrm{CoDy}_{0.1} \mathrm{Fe}_{1.9} \mathrm{O}_{4}$ nanoparticles: influence@pH, J. Nanopart. Res. 15 (2013) 1976 
[21] S. E. Shirsath, M. L. Mane, Y. Yasukawa, X. Liu, A. Morisakoa, Self-ignited high temperature synthesis and enhanced super-exchange interactions of $\mathrm{Ho}^{3+}-\mathrm{Mn}^{2+}-\mathrm{Fe}^{3+}-\mathrm{O}^{2-}$ ferromagnetic nanoparticles, Phys. Chem. Chem. Phys. 16 (2014) 2347-2357

[22] S.E. Shirsath, D. Wang, S.S. Jadhav, M.L. Mane, S. Li, Ferrites obtained by sol-gel method L. Klein, M. Aparicio, A. Jitianu (Eds.), Handbook of Sol-Gel Science and Technology, Springer, Cham (2018), pp. 695-735.

[23] A. Baykal, S. Esir, A. Demir, S. Güner, Magnetic and optical properties of $\mathrm{Cu}_{1-\mathrm{x}} \mathrm{Zn}_{\mathrm{x}} \mathrm{Fe}_{2} \mathrm{O}_{4}$ nanoparticles dispersed in a silica matrix by a sol-gel auto-combustion method, Ceram. Int. 41 (2015) 231-239.

[24] S. Güner, Md. Amir, M. Geleri, M. Sertkol, A. Baykal, Magneto-Optical Properties of $\mathrm{Mn}^{3+}$ substituted $\mathrm{Fe}_{3} \mathrm{O}_{4}$ Nanoparticles, Ceram. Int. 41 (2015) 10915-10922.

[25] John P. Blitz, Diffuse Reflectance Spectroscopy, Modern Techniques in Applied Molecular Spectroscopy, Chp. 5, ISBN 0-471-12359-5 C 1998 John Wiley \& Sons, Inc.

[26] J. Tauc, R. Grigorovici and A. Vancu, Optical properties and electronic structure of amorphous germanium, Physica Status Solidi 15 (1966) 627-637.

[27] A Baykal, S Guner, H Gungunes, KM Batoo, Md Amir, A Manikandan, Magneto Optical Properties and Hyperfine Interactions of $\mathrm{Cr}^{3+}$ Ion Substituted Copper Ferrite Nanoparticles, Journal of Inorganic and Organometallic Polymers and Materials 28 (2018) 2533-2544. 
[28 P.H. Nam, N.X. Phuc, P.H. Linh, L.T. Lu, D.H. Manh, P.T. Phong, In-JaLee, Effect of zinc on structure, optical and magnetic properties and magnetic heating efficiency of $\mathrm{Mn}_{1}$ ${ }_{x} \mathrm{Zn}_{x} \mathrm{Fe}_{2} \mathrm{O}_{4}$ nanoparticles, Physica B: Condensed Matter 550 (2018) 428-435.

[29] A. Ashok, L.J. Kennedy, J.J. Vijaya, Structural, optical and magnetic properties of $\mathrm{Zn}_{1-}$ ${ }_{x} \mathrm{Mn}_{\mathrm{x}} \mathrm{Fe}_{2} \mathrm{O}_{4}(0 \leq x \leq 0.5)$ spinel nano particles for transesterification of used cooking oil, J. Alloys Compd. 780 (2019) 816-828.

[30] A. Baykal, S. Güner, A. Demir, Synthesis and magneto-optical properties of triethylene glycol stabilized $\mathrm{Mn}_{1-\mathrm{x}} \mathrm{Zn}_{\mathrm{x}} \mathrm{Fe}_{2} \mathrm{O}_{4}$ nanoparticles, J. Alloys Compd. 619 (2015) 5-11.

[31] A. Demir, S. Güner, Y. Bakıs, S. Esir, A. Baykal, Magnetic and Optical Properties of $\mathrm{Mn}_{1-}$ ${ }_{x} \mathrm{Zn}_{x} \mathrm{Fe}_{2} \mathrm{O}_{4}$ Nanoparticles, Journal of Inorganic and Organometallic Polymers and Materials 24 (2014) 729-736.

[32] A. Baykal, S. Güner, A. Demir, S. Esir, F. Genç, Effect of Zinc substitution on magnetooptical properties of $\mathrm{Mn}_{1-\mathrm{x}} \mathrm{Zn}_{\mathrm{x}} \mathrm{Fe}_{2} \mathrm{O}_{4} / \mathrm{SiO}_{2}$ nanocomposites, Ceram. Int. 40 (2014) 1340113408.

[33] M. Chand, A. Kumar, Annveer, S. Kumar, A. Shankar, R.P. Pant, Investigations on MnxZn1$\mathrm{xFe} 2 \mathrm{O} 4(\mathrm{x}=0.1,0.3$ and 0.5$)$ nanoparticles synthesized by sol-gel and co-precipitation methods, Ind J Eng Mater Sci 18 (2011) 385

[34] Z.Ž. Lazarević, Č. Jovalekić, A. Milutinović, D. Sekulić, V.N. Ivanovski, A. Rečnik, et al., Nanodimensional spinel $\mathrm{NiFe}_{2} \mathrm{O}_{4}$ and $\mathrm{ZnFe}_{2} \mathrm{O}_{4}$ ferrites prepared by soft mechanochemical synthesis, J Appl. Phys. 113 (2013) 187221. 
[35] M.A. Almessiere, Y. Slimani, S. Güner, A. Baykal, I. Ercan, Effect of dysprosium substitution on magnetic and structural properties of $\mathrm{NiFe}_{2} \mathrm{O}_{4}$ nanoparticles, Journal of Rare Earths 37 (2019) 871-878.

[36] C.F. Zhang, X.C. Zhong, H.Y. Yu, Z.W. Liu, D.C. Zeng, Effects of cobalt doping on the microstructure and magnetic properties of $\mathrm{Mn}-\mathrm{Zn}$ ferrites prepared by the co-precipitation method, Phys B Cond Matter 404 (2009) 2327.

[37] E.C. Stoner, E. Wohlfarth, A mechanism of magnetic hysteresis in heterogeneous alloys, Philosophical Transactions of the Royal Society of London. Series A, Mathematical and Physical Sciences, 240 (1948) 599-642.

[38] X. Li, Y. Hou, Q. Zhao, L. Wang, A general, one-step and template-free synthesis of spherelike zinc ferrite nanostructures with enhanced photocatalytic activity for dye degradation, J. Colloid Interf. Sci. 358 (2011) 102-108.

[39] M.A. Almessiere, Y. Slimani, U. Kurtan, S. Guner, M. Sertkol, Sagar E. Shirsath, S. Akhtar, A. Baykal, I. Ercan, Structural, magnetic, optical properties and cation distribution of nanosized $\mathrm{Co}_{0.7} \mathrm{Zn}_{0.3} \mathrm{Tm}_{\mathrm{x}} \mathrm{Fe}_{2-\mathrm{x}} \mathrm{O}_{4}(0.0 \leq \mathrm{x} \leq 0.04)$ spinel ferrites synthesized by ultrasonic irradiation, Ultrasonics Sonochemistry 58 (2019) 104638.

[40] M.A. Almessiere, Y. Slimani, A.D. Korkmaz, N. Taskhandi, M. Sertkol, A. Baykal, Sagar E. Shirsath, İ. Ercan, B. Ozçelik, Sonochemical synthesis of $\mathrm{Eu}^{3+}$ substituted $\mathrm{CoFe}_{2} \mathrm{O}_{4}$ nanoparticles and their structural, optical and magnetic properties, Ultrasonics Sonochemistry $58(2019) 104621$.

[41] Mohammad Javad Nasr Isfahani, Maxym Myndyk, Dirk Menzel, Armin Feldhoff, Jamshid Amighian, Vladimir Šepelák, Magnetic properties of nanostructured MnZn ferrite, J. Magn. Magn. Mater. 321 (2009) 152-156. 
[42] J.M.D. Coey, Noncollinear spin arrangement in ultrafine ferrimagnetic crystallites, Phys. Rev. Lett. 27 (1971) 1140-1142.

[43] Y. Slimani, M. Almessiere, M. Nawaz, A. Baykal, S. Akhtar, I. Ercan, I. Belenli, Effect of bimetallic $(\mathrm{Ca}, \mathrm{Mg})$ substitution on magneto-optical properties of $\mathrm{NiFe}_{2} \mathrm{O}_{4}$ nanoparticles, Ceram. Int. 45 (2019) 6021-6029.

[44] M. Almessiere, A.D. Korkmaz, Y. Slimani, M. Nawaz, S. Ali, A. Baykal, Magneto-optical properties of rare earth metals substituted Co-Zn spinel nanoferrites, Ceram. Int. 45 (2019) 3449-3458.

[45] B. Parvatheeswara Rao, Chong-Oh Kim, Cheol Gi Kim, I. Dumitru, L. Spinu, O. F. Caltun, Structural and Magnetic Characterizations of Coprecipitated Ni-Zn and Mn-Zn Ferrite Nanoparticles, IEEE Transactions on Magnetics 42 (2006) 2858.

[46] Gh.R. Amiri, M.H. Yousefi, M.R. Abolhassani, S. Manouchehri, M.H. Keshavarz, S. Fatahian, Magnetic properties and microwave absorption in $\mathrm{Ni}-\mathrm{Zn}$ and $\mathrm{Mn}-\mathrm{Zn}$ ferrite nanoparticles synthesized by low-temperature solid-state reaction, J. Magn. Magn. Mater. 323 (2011) $730-734$.

[47] C. Rath, K. K. Sahu, S. Anand, S. K. Date, N. C. Mishra, R. P. Das, Preparation and characterization of nanosize Mn-Zn ferrite, J. Magn. Magn. Mater. 202 (1999) 77-84.

[48] E. Ranjith kumar, R. Jayaprakash, M.S. Seehra, T. Prakash, Sanjay Kumar, Effect of $\alpha-\mathrm{Fe}_{2} \mathrm{O}_{3}$ phase on structural, magnetic and dielectric properties of Mn-Zn ferrite nanoparticles, J. Phys. Chem. Solids 74 (2013) 943-949.

[49] J. Azadmanjiri, Preparation of Mn-Zn ferrite nanoparticles from chemical sol-gel combustion method and the magnetic properties after sintering, J. Non-Crystalline Solids 353 (2007) 4170-4173. 
[50] Adeela Nairan, Maaz Khan, Usman Khan, Munawar Iqbal, Saira Riaz, Shahzad Naseem, Temperature-Dependent Magnetic Response of Antiferromagnetic Doping in Cobalt Ferrite Nanostructures, Nanomaterials 6 (2016) 73.

[51] Y. Slimani, H. Güngüneş, M. Nawaz, A. Manikandan, H. El Sayed, M. Almessiere, H. Sözeri, S. Shirsath, I. Ercan, A. Baykal, Magneto-optical and microstructural properties of spinel cubic copper ferrites with Li-Al co-substitution, Ceram. Int. 44 (2018) 14242-14250.

[52] D. Peddis, C. Cannas, G. Piccaluga, E. Agostinelli, D. Fiorani, Surface spin freezing effects on enhanced saturation magnetization and magnetic anisotropy in $\mathrm{CoFe}_{2} \mathrm{O}_{4}$ nanoparticles, Nanotechnology 21 (2010) 125705.

[53] M.A. Almessiere, Y. Slimani, M. Sertkol, F.A. Khan, M. Nawaz, H. Tombuloglu, E.A. AlSuhaimi, A. Baykal, Ce-Nd Co-substituted nanospinel cobalt ferrites: An investigation of their structural, magnetic, optical, and apoptotic properties, Ceram. Int. 45 (2019) 1614716156.

[54] D. Peddis, C. Cannas, G. Piccaluga, E. Agostinelli, D. Fiorani, Surface spin freezing effects on enhanced saturation magnetization and magnetic anisotropy in $\mathrm{CoFe}_{2} \mathrm{O}_{4}$ nanoparticles, Nanotechnology 21 (2010) 125705.

[55] Z. Qiaoqiao, X. Yang, J. Guan, Applications of Magnetic Nanomaterials in Heterogeneous Catalysis, ACS Applied Nano Materials 2 (2019) 4681-4697.

[56] B. Javad, T. Ramezani, A. Divsalar, M. Mousavi, A. Seyedarabi, Induction of apoptosis by green synthesized gold nanoparticles through activation of caspase-3 and 9 in human cervical cancer cells, Avicenna journal of Medical Biotechnology 8 (2016) 75. 
[57] J. Mytych, L. Anna, Z. Jacek, W. Maciej, Gold nanoparticles promote oxidant-mediated activation of NF-kB and 53BP1 recruitment-based adaptive response in human astrocytes, BioMed research international, 2015.

[58] S. Rehman, M.A. Ansari, M.A Alzohairy, M.N Alomary, B.R. Jermy, R. Shahzad, N. Tashkandi, Z.H. Alsalem, Antibacterial and Antifungal Activity of Novel Synthesized Neodymium-Substituted Cobalt Ferrite Nanoparticles for Biomedical Application, Processes, 7 (2019) 714.

[59] A. Fekri, A. Ahmed, J. Alam, A.K. Shukla, M. Alhoshan, M.A. Ansari, W.A. Al-Masry, S. Rehman, M. Alam, Evaluation of antibacterial and antifouling properties of silver-loaded GO polysulfone nanocomposite membrane against Escherichia coli, Staphylococcus aureus, and BSA protein, Reactive and Functional Polymers 140 (2019) 136-47.

[60] E.Asma M, T.E Youssef, S.S. Al-Jameel, H.H. Mohamed, M.A. Ansari, S. Rehman, S. Akhtar, Synthesis of an Activatable Tetra-Substituted Nickel Phthalocyanines-4 (3H)quinazolinone Conjugate and Its Antibacterial Activity, Advances in pharmacological sciences, 2019.

[61] C. Elsa, A. Rajan, G. Baskar, Synthesis of manganese dioxide nanoparticles using coprecipitation method and its antimicrobial activity, Int. J. Modern Sci. Technol. 1 (2016) $17-22$.

[62] de Toledo, Lucas de Alcantara Sica, H.C. Rosseto, M.L. Bruschi, Iron oxide magnetic nanoparticles as antimicrobials for therapeutics, Pharmaceutical Development and Technology 23 (2018) 316-23. 
Figures

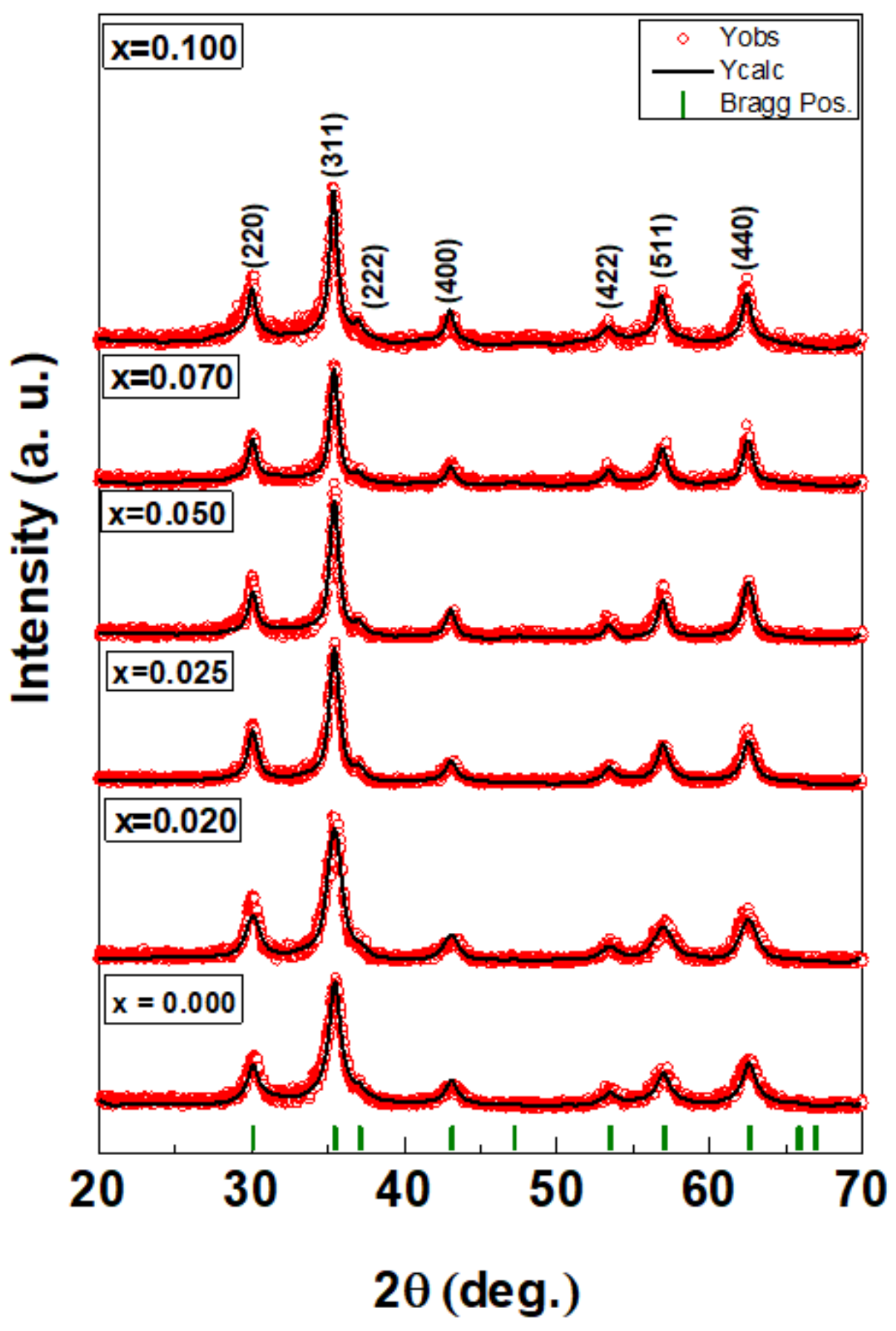

Figure 1

The XRD patterns of the studied CDMZNSFs. 


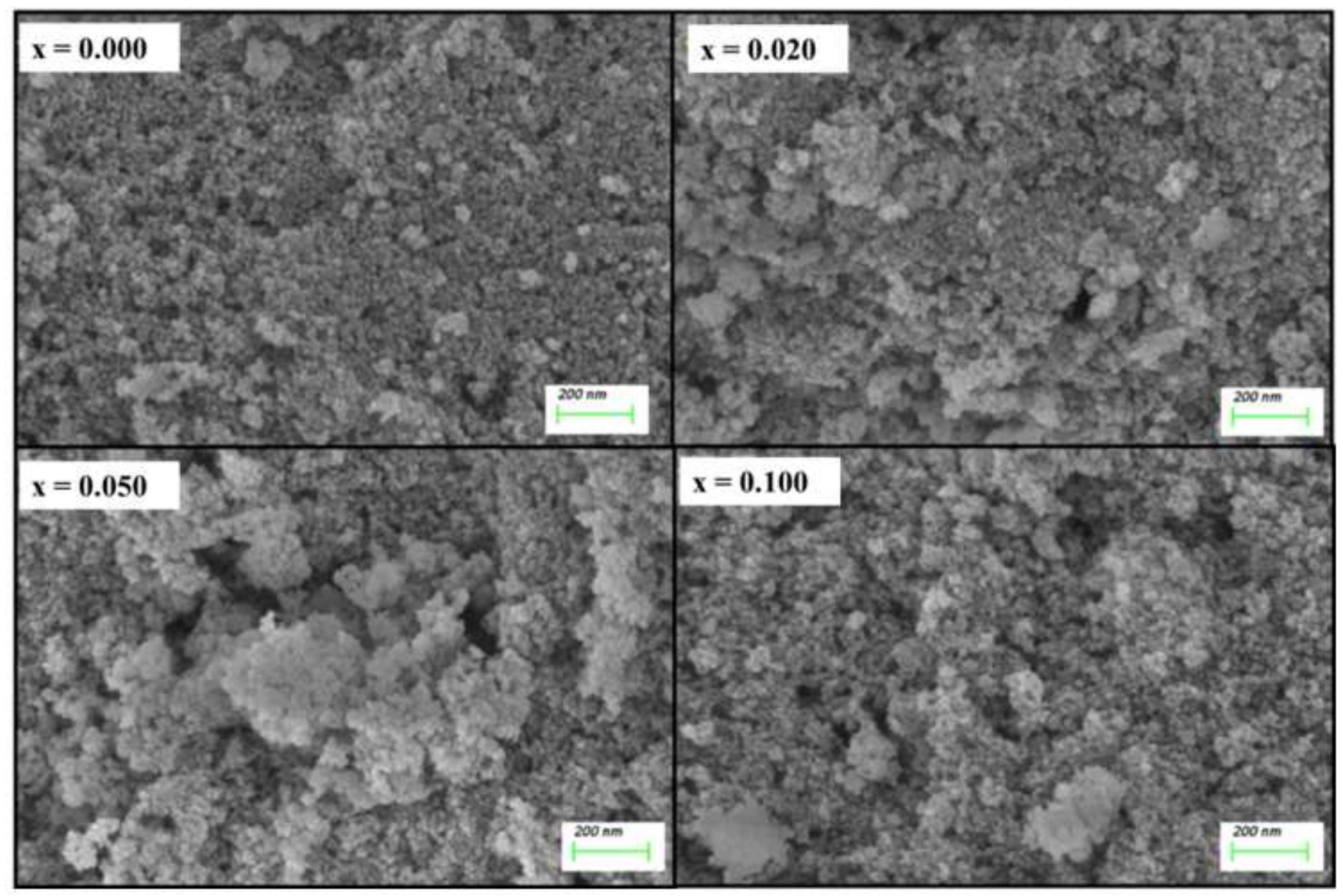

Figure 2

The SEM images of the synthesized CDMZNSFs.
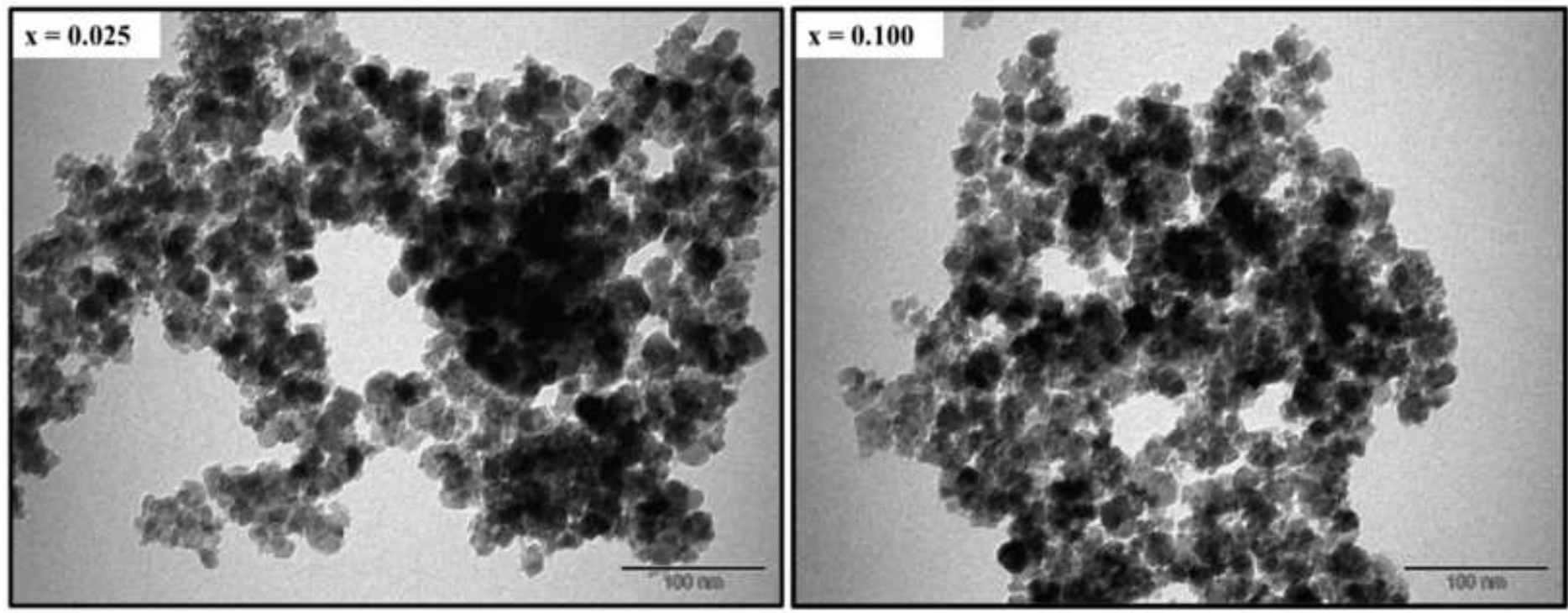

Figure 3 
The TEM micrographs of the synthesized CDMZNSFs.

$$
\mathbf{x}=\mathbf{0 . 0 2 0}
$$
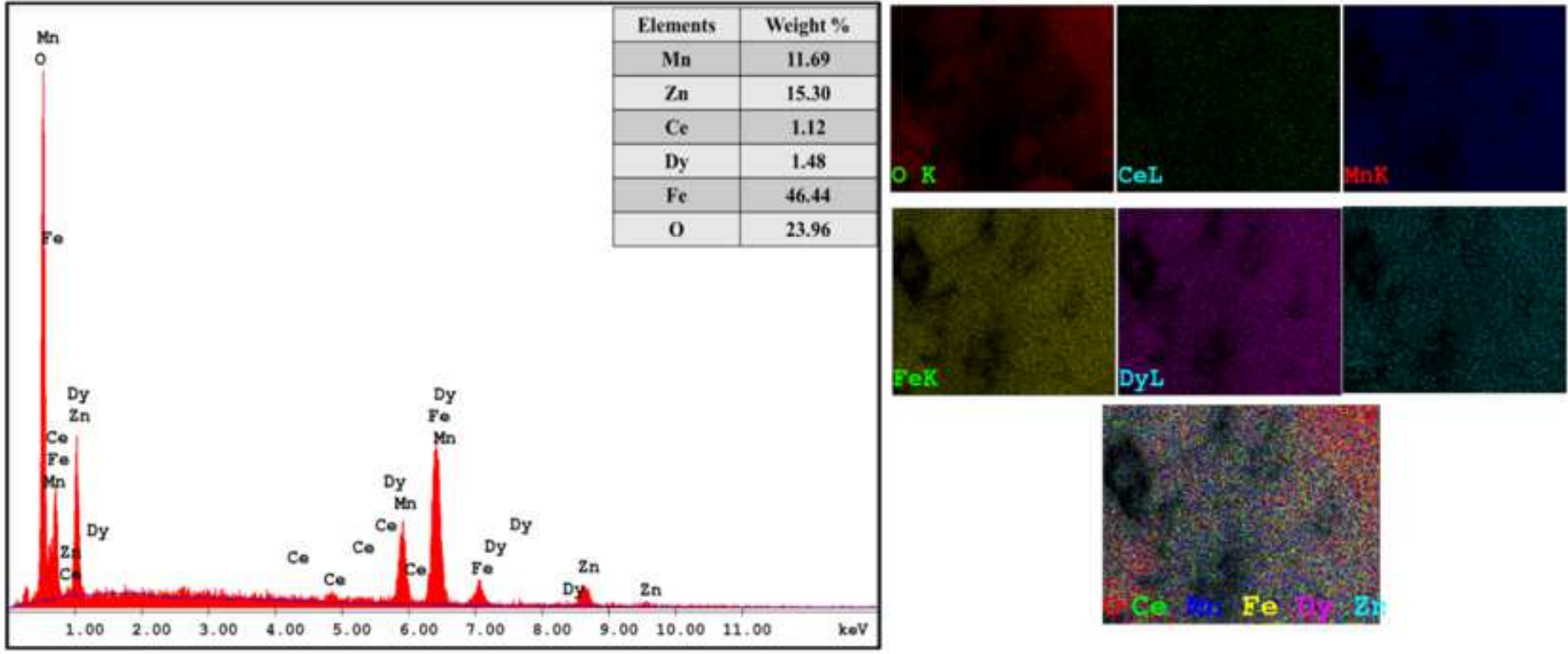

$\mathrm{x}=\mathbf{0 . 0 5 0}$
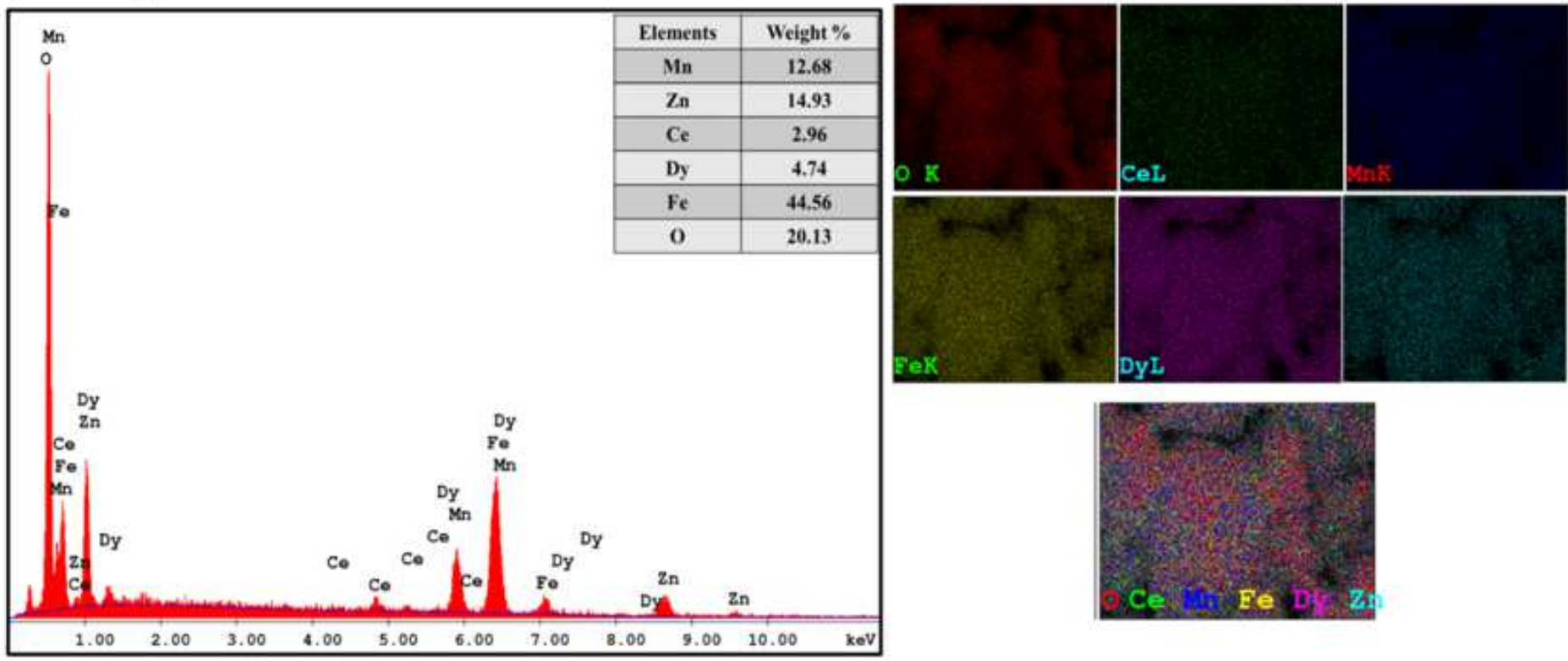

Figure 4

The EDX spectra and corresponding elemental maps of the synthesized CDMZNSFs (Inset: measured Weight\% of various elements). 


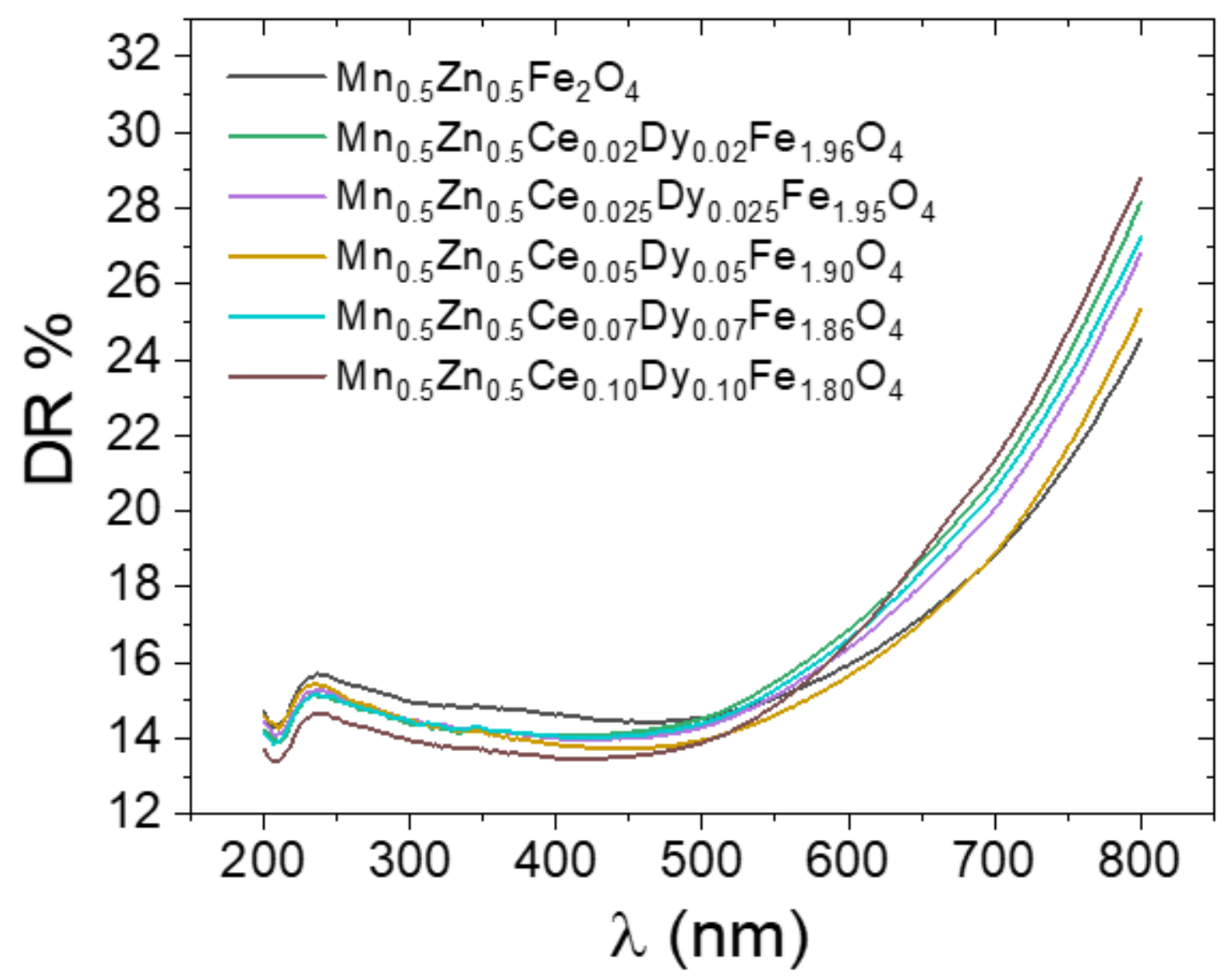

Figure 5

The diffuse reflectance spectra of the prepared CDMZNSFs. 

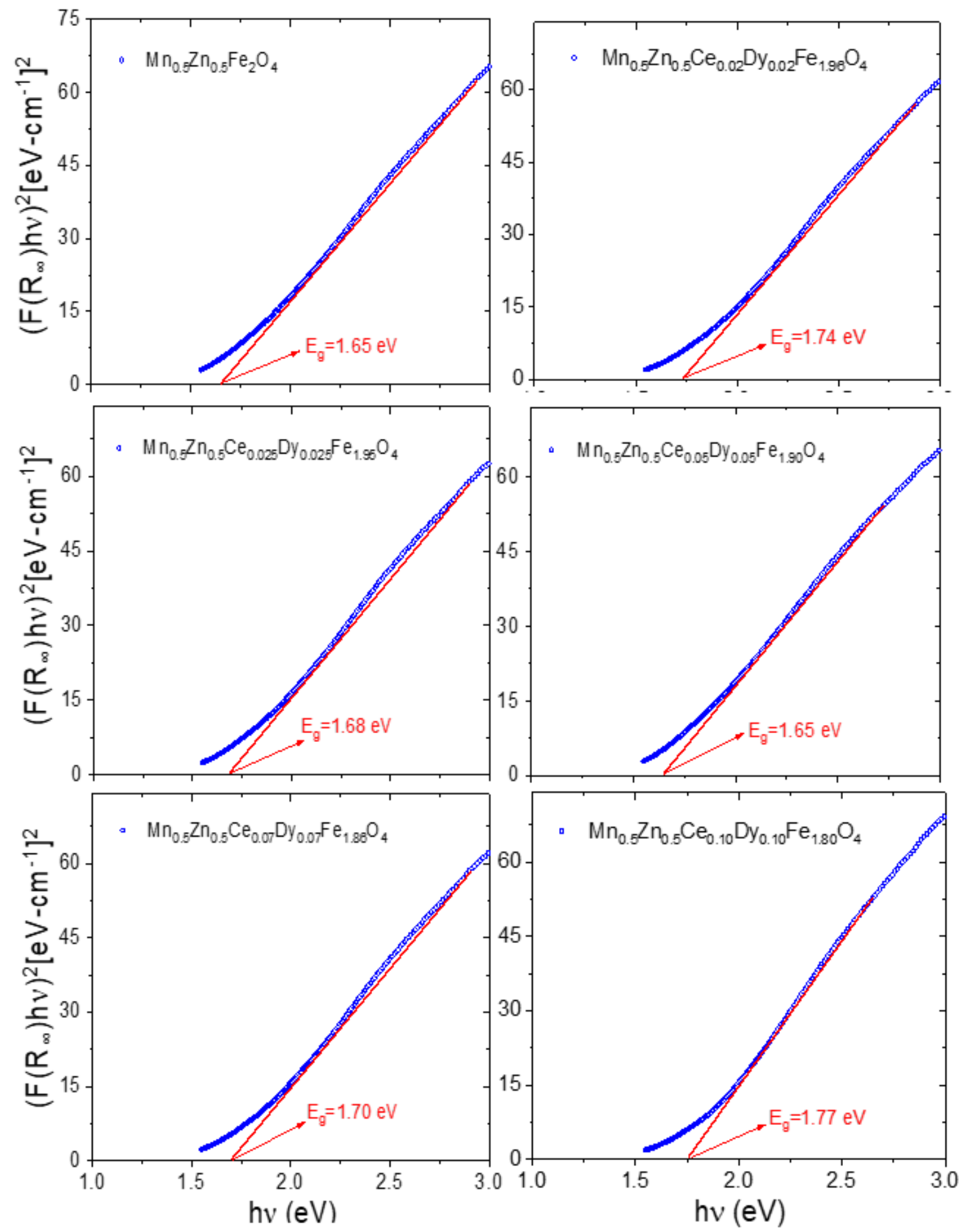

Figure 6

Tauc plots for all the obtained CDMZNSFs showing the estimated value of the optical band gap energies. 


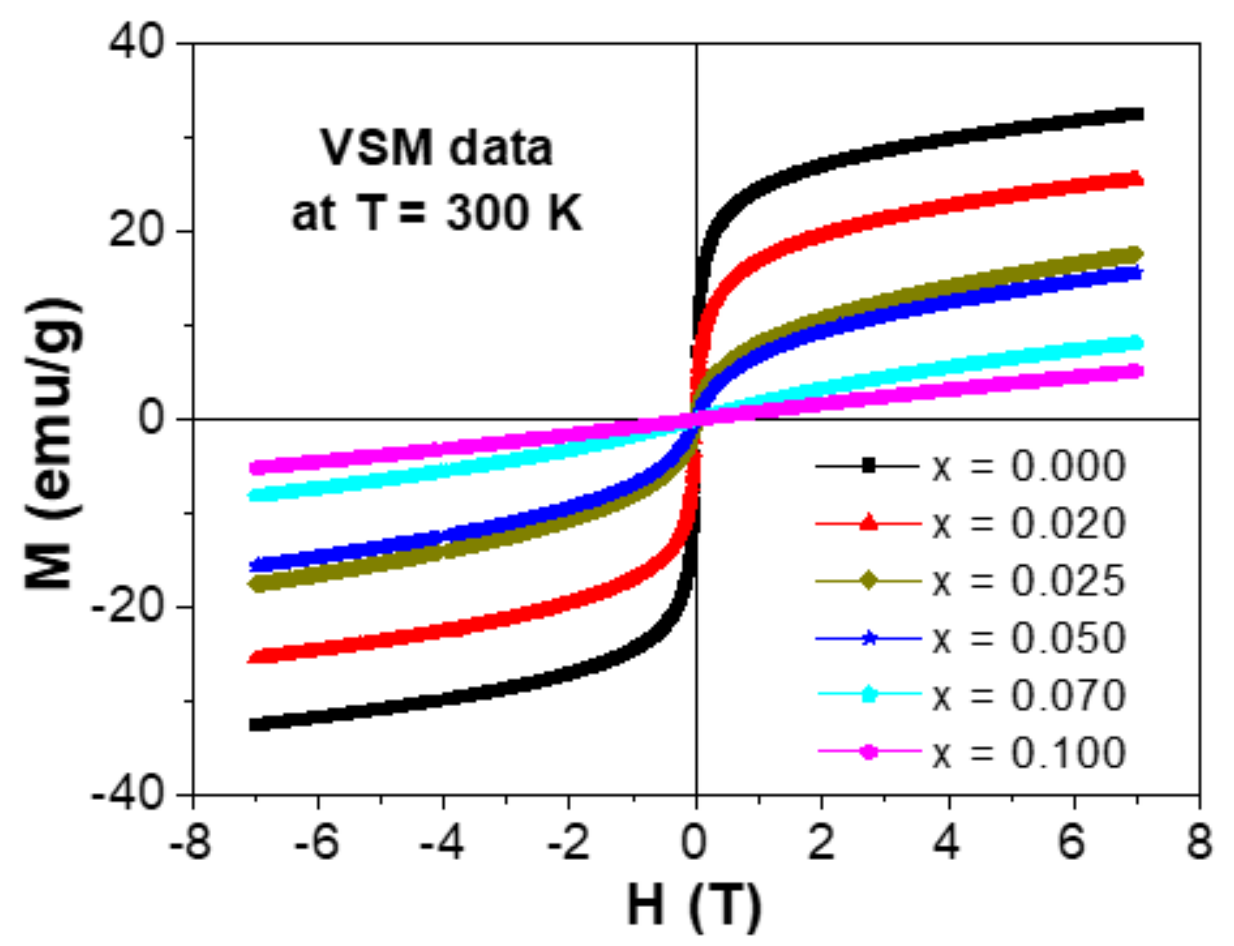

Figure 7

The RT hysteresis loops of all the obtained CDMZNSFs.

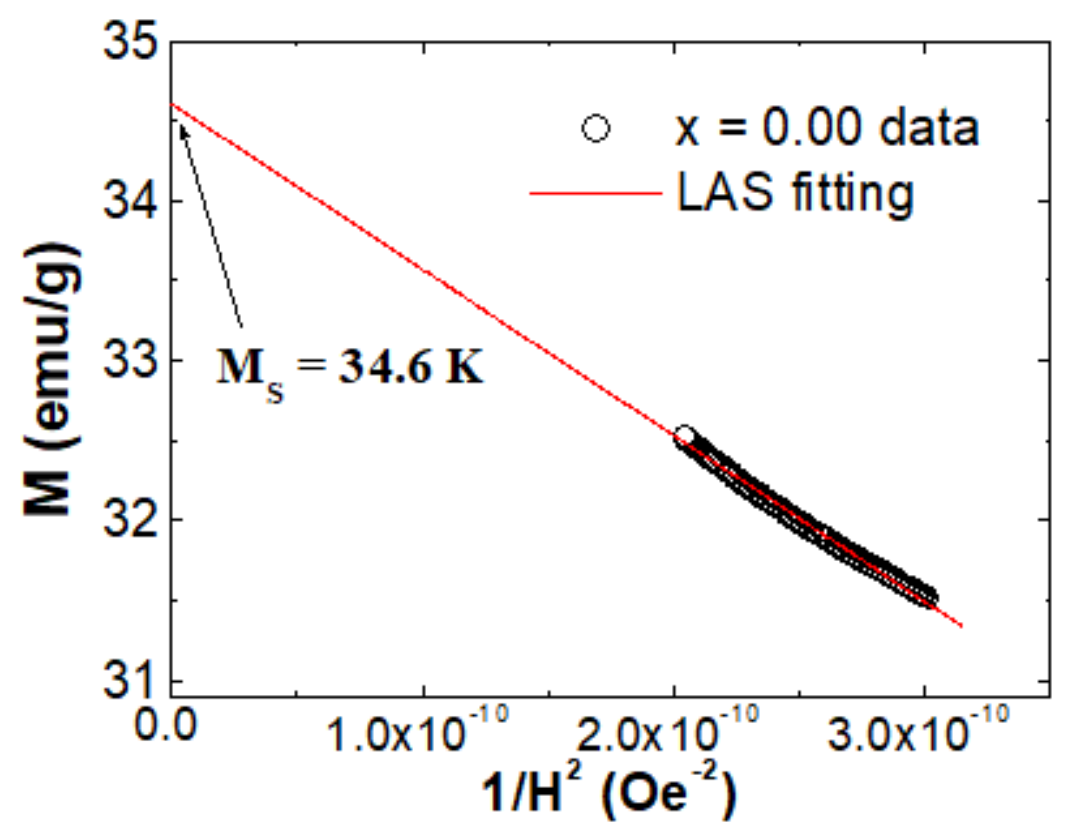

Figure 8

The M against 1/H2 plot of the undoped CDMZNSFs. The solid line shows the LAS fit. 


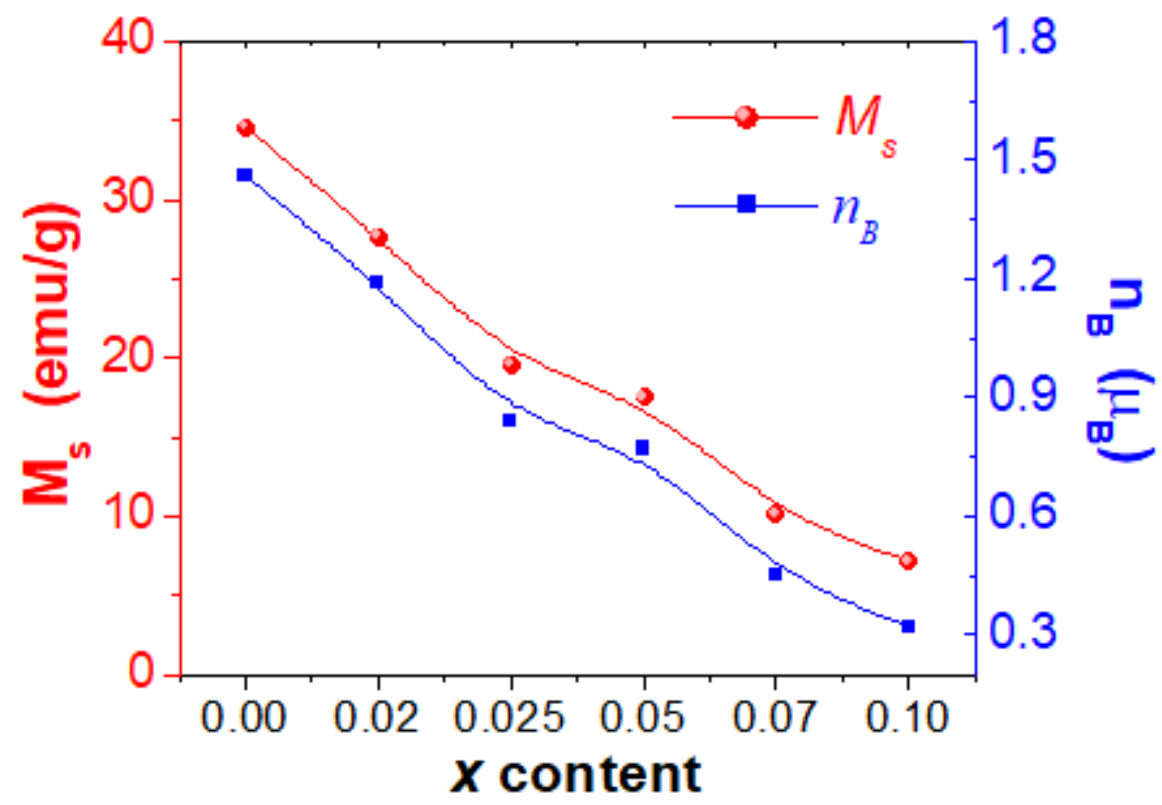

Figure 9

Dependence of Ms and n_B on the co-substituents (Ce3+/Dy3+) contents.

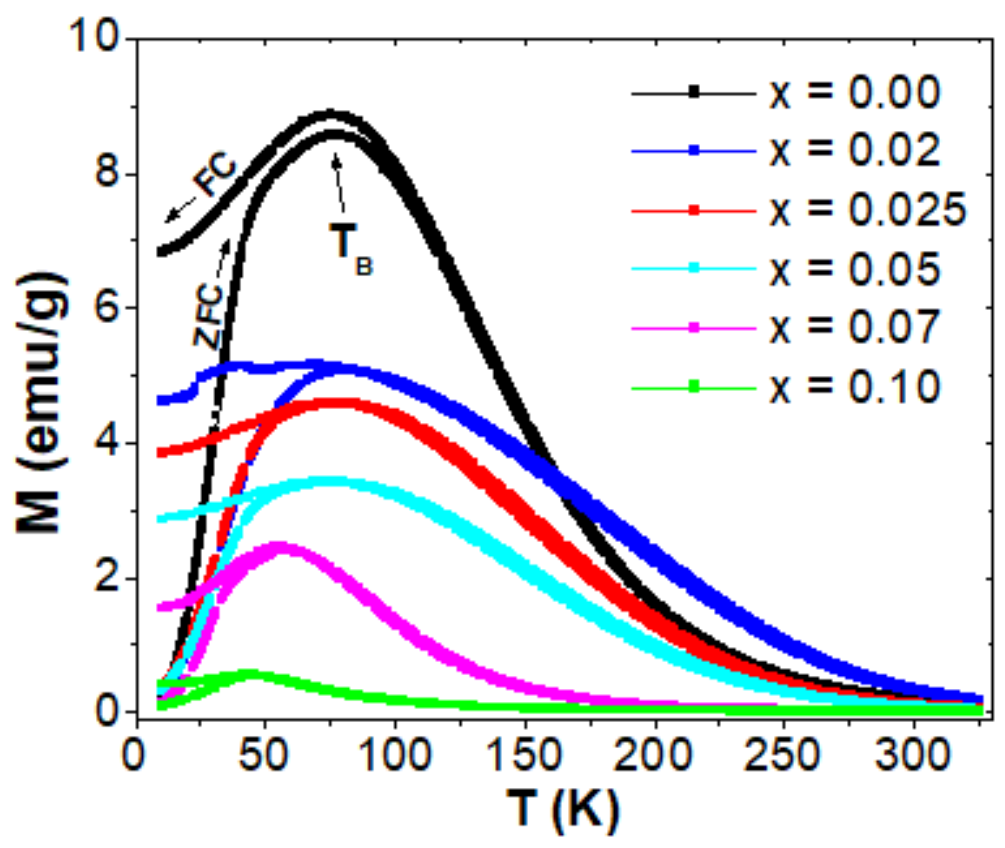

Figure 10

ZFC-FC magnetizations of the prepared CDMZNSFs at the applied magnetic field of 100 Oe. 

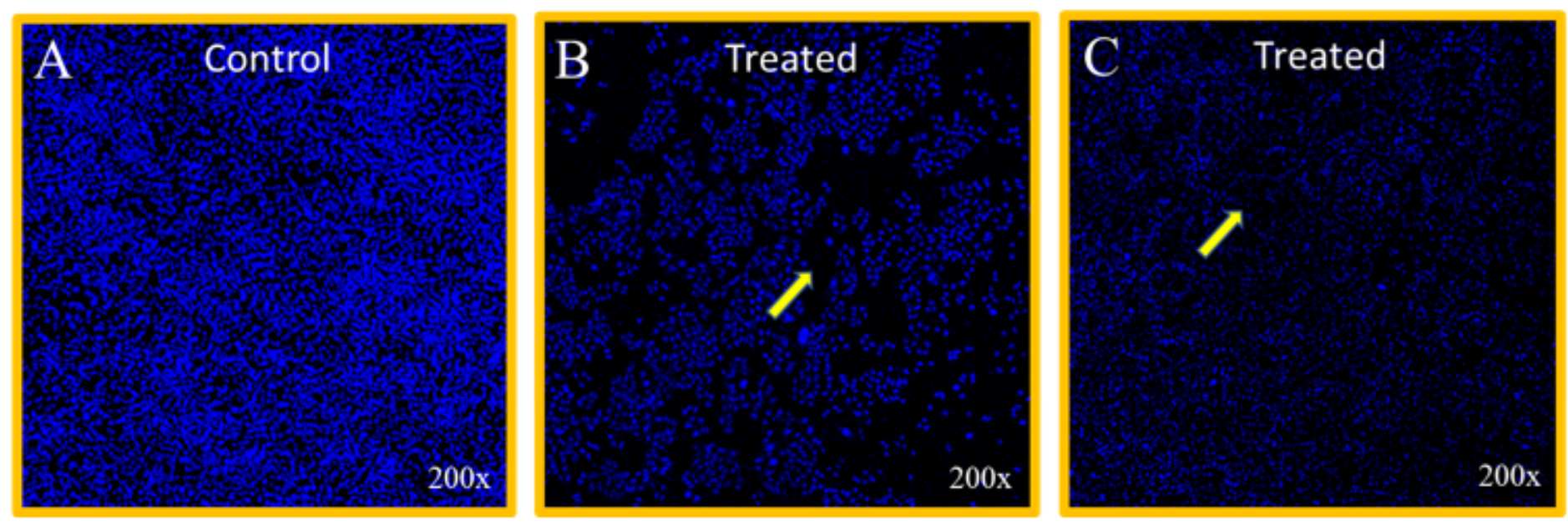

\section{Figure 11}

The cell morphologies after DAPI staining (48 $\mathrm{h}$ ) for the (a) untreated control group, (b) CDMZNSFstreated $(x=0.00$ dose of $0.74 \mu \mathrm{g} / \mathrm{mL}$ ) cancer cells and (c) CDMZNSFs-treated $(x=0.10$ dose of 2.35 $\mu \mathrm{g} / \mathrm{mL}$ ) cancer cells. Arrow heads shows the nuclear staining-mediated decay of the cells.

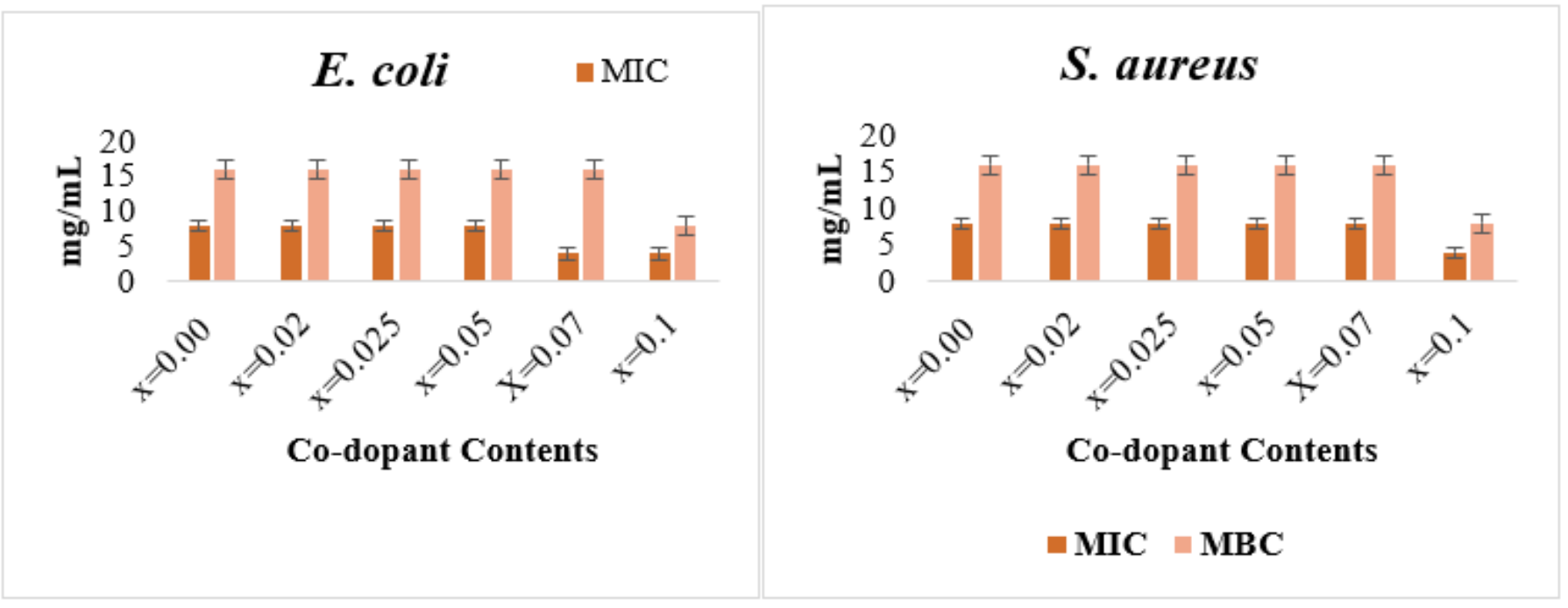

(a)

(b)

\section{Figure 12}

The measured values of MIC/MBC for the CDMZNSFs-treated (a) E.coli, and (b) S. aureus bacteria. 

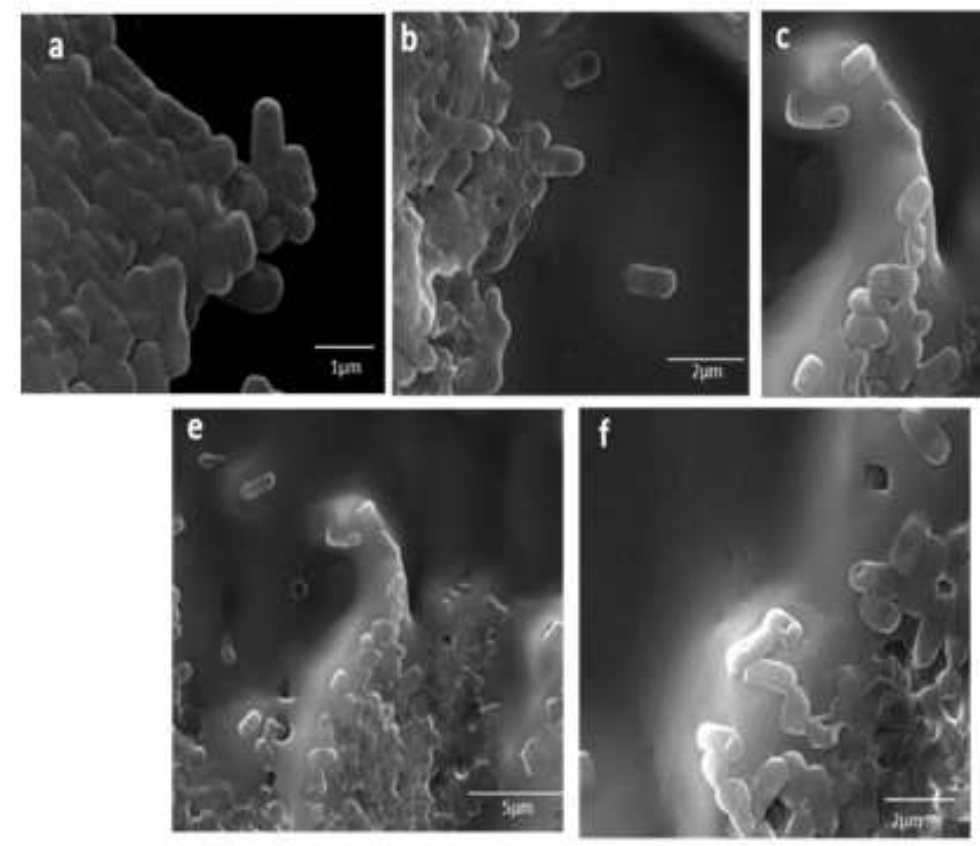

(a1)
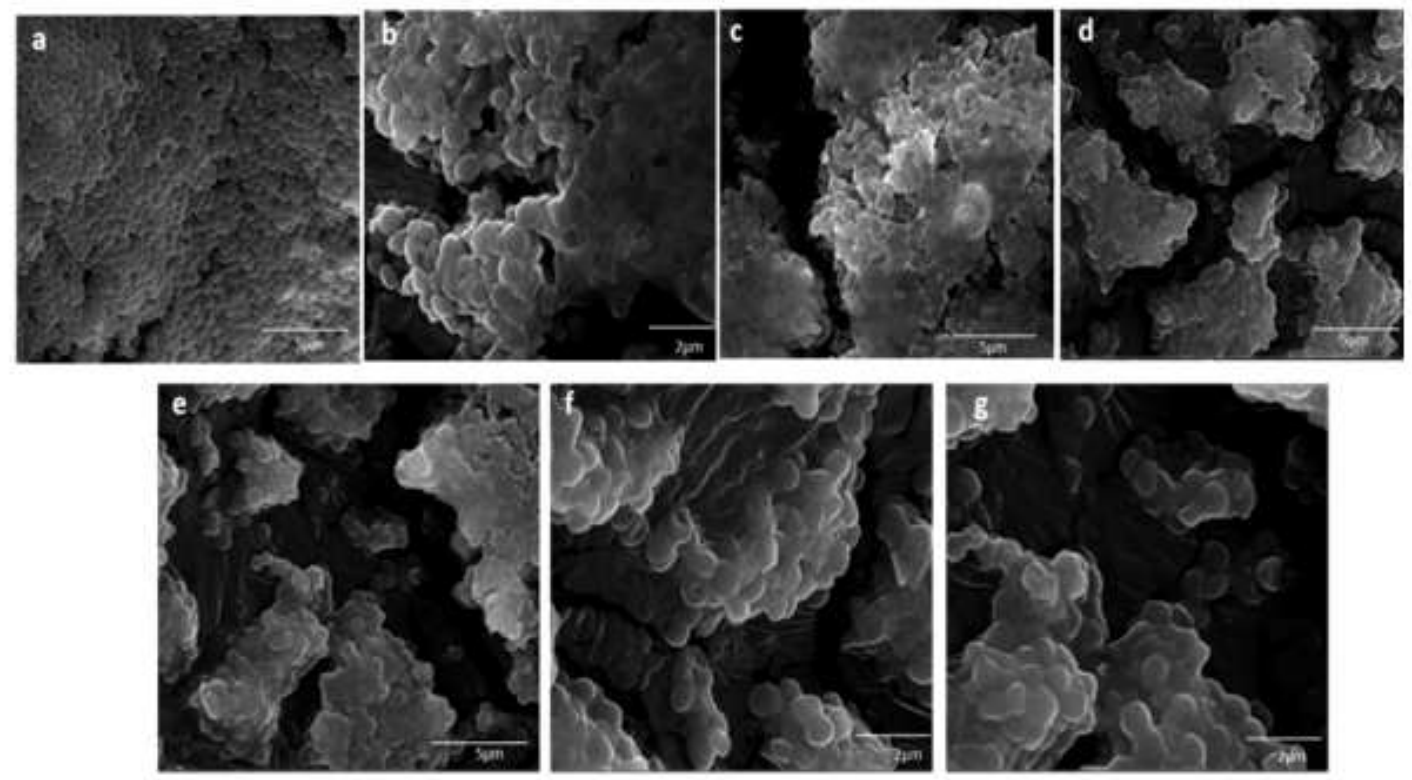

(b1)

\section{Figure 13}

SEM micrographs of the CDMZNSFs-treated bacteria (a1) E. coli (b1) S. aureus. a) untreated cells(control), b) $x=0.00$, c) 0.02 , d) 0.025 , e) 0.05 , f) 0.07 and g) 0.01 . 